\title{
Race and Competitiveness in Brazilian Elections: Evaluating the Chances of Black and Brown Candidates through Quantile Regression Analysis of Brazil's 2014 Congressional Elections*
}

\author{
Carlos Augusto Machado \\ https://orcid.org/0000-0001-5379-5706
}

Institute of Political Science, Universidade de Brasília, Brasília, Distrito Federal, Brazil

Luiz Augusto Campos

https://orcid.org/0000-0003-2153-547X

Institute of Social and Political Studies, Universidade do Estado do Rio de Janeiro, Rio de Janeiro, Rio de Janeiro, Brazil

\section{Filipe Recch}

https://orcid.org/0000-0001-7782-2641

Stanford Graduate School of Education, Stanford University, California, United States

\begin{abstract}
Although the proportion of black, brown and indigenous electoral candidates in Brazil is close to the proportion of blacks, browns and indigenous in the general population, the proportion elected to the country's Federal Congress is significantly lower. Statistical techniques such as linear or logistic regression are typically used to estimate the effect of a particular variable such as color/race or gender on a candidate's electoral performance. However, in Brazilian elections, characterized by substantive, asymmetrical differences such as extreme variations in campaign finance distribution, the efficacy of these types of regression models is limited. Such being the case in Brazil's open list proportional representation system, we propose quantile regression as the most suitable means for estimating the relationship between voting and other variables such as race/color, because it enables us to estimate relationships between the variables of interest across several distribution quantiles. Quantile regression models show that black and brown candidates get as many as $40 \%$ fewer votes than white candidates in higher vote distribution quantiles. Furthermore, analysis of access to campaign financing finds that black and brown candidates on average garner only $75 \%$ of the funds available to white candidates at quantile 80 of campaign finance distribution. This drops to $65 \%$ at quantile 90.

Keywords: Race/color; elections; political parties; quantile regression; campaign finance.

http://dx.doi.org/10.1590/1981-3821201900030003

For data replication, see: https://doi.org/10.7910/DVN/UJMQ4W. This publication is registered

${ }^{*}$ A draft version of this paper was presented at the 10th Meeting of the Brazilian Association of Political Science, held in Belo Horizonte (MG), Brazil, from 08/30/2016 to 09/02/2016. The author Luiz Augusto Campos was funded by CNDCT-CNPq and Prociência-FAPERJ. We would like to express gratitude to the contributions of Thyago Simas in organizing the data used in the article.
\end{abstract} under a CC-BY Licence. 
Ithough some exponents of modern democracy hoped that universal suffrage would bring rulers and ruled closer together (e.g. ADAMS, 1856, p. 195; MILL, 1964; WILSON, 1896, p. 391), the current composition of most representative assemblies around the world demonstrates that this has not happened. The composition of political representation via elections tends to reinforce pre-existing social hierarchies (MANSBRIDGE, 1999), even in contexts where the political culture favors a greater degree of political inclusion (NORRIS and INGLEHEART, 2001). Dominant social groups tend to translate their privileges into greater chances of electoral success, while subordinate groups tend to be excluded from political power, even when they make up the majority of the electorate.

This becomes particularly clear when we look at the political underrepresentation of some sectors of Brazilian society such as workers, women and blacks. Although they make up most of the Brazilian population, these three groups are severely underrepresented in spheres of power. Brazil's elected leaders are usually upper-class white men (JOHNSON, 1998; MIGUEL, MARQUES and MACHADO, 2015). Although there is a reasonable amount of consensus about this diagnosis, there is no such consensus on the causes for this exclusion. This is because it is not always easy to estimate the specific weight that variables such as social class, race/color or gender have on different types of candidates' electoral chances.

This problem is particularly complex in relation to the color/race of Brazilian candidates. As is widely known, Brazil's history of slavery and current discriminatory practices have condemned the non-white population to the base of the social pyramid. Because of this, it is difficult to determine to what extent the absence of Afro-Brazilians in politics is a result of the marginalization of the lower classes or racial discrimination mechanisms. Moreover, the political underrepresentation of nonwhites seems to have different causes than that of women. Although the literature on the subject offers varied explanations for this 
phenomenon ${ }^{1}$, there is some consensus that women are often excluded from politics even before elections occur, when party lists are being drawn up (LAWLESS, 2012). Something quite different seems to happen with Afro-Brazilian candidates. Research on the topic shows that the proportion of non-whites on party lists is relatively close to that of the general population (BUENO and DUNNING, 2013; CAMPOS and MACHADO, 2015a, 2015b). Thus, the filters that impede the representation of this group seem to be different from those imposed on women. Non-white women are subjected to a double filter to political access; analyses of candidacy nominations find that the largest discrepancy between the candidate percentages and population size occurs in this category (CAMPOS and MACHADO, 2015b).

Researchers have traditionally used statistical techniques such as linear or logistic regression (BUENO and DUNNING, 2013; CAMPOS and MACHADO, 2015a) to estimate the effect of traits such as color/race or gender on a candidate's election chances. Linear regression models estimate the correspondence between the averages of independent variables and those of a dependent variable (MOSTELLER and TUKEY, 1977, p. 266). However, analyses focused on distribution averages are limited when there are substantial differences in significance for extreme points of the distribution (KOENKER and HALLOCK, 2001). In these cases, averages are not good descriptive parameters for the complete series. One example of this is the typical vote distribution in Brazilian elections.

In a logistic model with a binary dependent variable, it is necessary to define an arbitrary prior cut in a continuous variable of interest. This is the case with the variable of number of votes in Brazilian elections. Using a quantile model avoids this problem by estimating the relationship between variables and the quantiles of interest of the dependent variable.

The Brazilian open list proportional representation system distributes seats in municipal, state and federal legislatures to political parties and coalitions based on the total votes received by said parties and coalitions. Therefore, it is in the parties' and coalitions' best interests to register as many candidates as possible and

${ }^{1}$ On this subject, see Pinto (1994), Miguel (2000), Miguel and Queiroz (2006), and Araújo e Alves (2007). 
Race and Competitiveness in Brazilian Elections: Evaluating the Chances of NonWhite Candidates through Quantile Regression Analysis of Brazil's 2014 Congressional Elections

this is incentivized by electoral legislation (which we will talk about below). In the 2014 Federal Congressional Elections ${ }^{2}$, parties/coalitions registered a total of 5,866 candidates from 224 party lists, all of whom were competing for a mere 513 seats, distributed in 27 lists for each federal unit (i.e. one of the 26 Brazilian states and the Federal District, abbreviated as 'FU'), with 08 to 70 seats each ${ }^{3}$. Clearly, the vast majority of candidates is registered for the sole purpose of increasing parties' or coalitions' chances of making it over the electoral quotient threshold. Such candidates are, ipso facto, not individually competitive. In practice, this means that only about $20 \%$ of candidates are involved in real electoral competition, while the remaining $80 \%$ have little or no chance of being elected. Linear regression models are not sensitive to this factor. The estimated coefficients used normally show the effects of the variables included in the model for both this $80 \%$ and the $20 \%$ that really matter. The use of linear regression models to explain competition between candidates in open list proportional representation systems is inadequate, then, where the object of interest is an explanation of such competition as exists between candidates that have real chances of being elected. One way to address this issue is through logistic regression that distinguishes between competitive (exceeding a certain number of votes) and non-competitive (CAMPOS and MACHADO, 2015a) candidacies. However, this approach necessitates an arbitrary cut to define the profiles of the candidates to be compared in the regression model.

The objective of this study is to investigate the relationship between white and non-white candidates' probabilities of winning elections and accessing campaign funding, while proposing an alternative regression model to those that have been used by other researchers on this theme to date (BOLOGNESI, PERISSINOTTO and CODATO, 2016; BUENO and DUNNING, 2013; CAMPOS and MACHADO, 2015a, 2015b; CODATO, LOBATO and CASTRO, 2017). Instead of linear

\footnotetext{
${ }^{2}$ Information on racial identification was only requested from the Higher Electoral Court (TSE) for candidates for elective office from the 2014 elections onwards.

${ }^{3}$ For comparison with a system whose electoral rules are similar to Brazil's, in the 2015 lower house elections in Finland 2,146 candidates competed for 200 available seats at a ratio of 10.7 candidates per seat, while in the 2014 Brazilian elections this ratio was 13.4. Source: <http://tilastokeskus.fi/til/evaa/2015/01/evaa_2015_01_2015-04-10_tie_001_en.html>.
} 
or logistic regression, we will use quantile regression to estimate independent variable coefficients in each of the quantiles for a given dependent variable (in this case, voting and campaign funding). If, for example, we designate votes as a dependent variable, quantile regression enables us to estimate the effects of other independent variables (social class, education level, gender, color/race, etc) on each of the candidate groups, from those who receive the least votes (lower quantiles) to those in strata which receive the most votes (upper quantiles). The same type of analysis can be made to measure the chances of each type of candidate to get campaign funding. This enables us to take different variables into account to estimate whites and non-whites, or men and women's different electoral chances. It also enables us to measure these odds in the different strata of electoral competition.

Therefore, the primary objective of this study is to show that models such as linear regression have limited potential when it comes to understanding electoral competition inequality in open list proportional representation systems. In addition to this proposal to use a new methodological tool, we also want to contribute to understanding on the relationship between race and candidates' electoral perspectives. Most findings show that strictly racial inequalities in terms of political opportunity are small, when we look at most candidates. This diagnosis changes, however, when we look specifically at the most competitive candidates, from which elected Members of Congress (MoCs) are effectively recruited. In this group, the color/race of the candidate has an important weight in decreasing chances of winning elections, even when controlling for other socioeconomic or political variables. This conclusion has important consequences for policies that aim to increase the proportion of AfroBrazilians elected to national office, as we will discuss in the conclusion.

\section{Theory and methodology}

In Brazilian legislative elections, each of the dozens of registered political parties can nominate hundreds of candidates to compete for seats in federal and statelevel assemblies. Therefore, vote distribution in Brazilian elections is highly asymmetric. The Gini coefficient of vote distribution for Members of Congress in the 2014 elections was 0.83 and all the elected candidates were from above the $85 \%$ quantile of 
Race and Competitiveness in Brazilian Elections: Evaluating the Chances of NonWhite Candidates through Quantile Regression Analysis of Brazil's 2014 Congressional Elections

vote distribution ${ }^{4}$. It is worth noting that, in this type of distribution, the average number of votes received by candidates is a poor indicator of their characteristics. On average, each candidate obtained $0.45 \%$ of the available votes in their respective federal unit, but this figure ignores the fact that proportionally most voted-for candidate received 35 times more votes than the average, while many received close to none. This situation strengthens the argument in favor of using quantile models to study access to votes in Brazil's open list proportional representation system.

Vote distribution in Brazilian elections is asymmetric because Brazilian law is quite permissive regarding the number of candidates each party or coalition can register. They can register the equivalent ${ }^{5}$ of $150 \%$ of the total number of contested seats in Congress in cases where the federal unit is represented by at least 21 seats, and $200 \%$ in federal units with 20 seats or less. When coalitions are taken into account, these values rise to $200 \%$ and $250 \%$ respectively. Added to this the fact that there is an incentive for parties/coalitions to register as many candidates as possible in order to gain an overall vote that will get them over the electoral quotient threshold.

Another factor that makes analysis of this type of series difficult is the fact that almost all of those elected to the position of $\mathrm{MoC}$ come from the last two deciles of the distribution - the $20 \%$ of candidates who received the most votes. To represent this relationship, in Figure 01 we present voting distribution for candidates according to electoral result. Congressional elections treat each FU as a single electoral district ${ }^{6}$, so to compare voting we calculated the relationship between votes per candidate and the district-wide electoral quotient ${ }^{7}$. In general,

\footnotetext{
${ }^{4}$ In the last election, 38 were elected from 587 candidates in the $80 \%-90 \%$ range of voting distribution, while 475 were elected from 586 candidates in the last decile.

${ }^{5}$ Since the 2016 elections, the percentages have changed as a result of slight changes in the Brazilian electoral process.

${ }^{6}$ The set of 27 federal units includes 26 states and the Federal District of Brasília.

${ }^{7}$ It is possible to use the percentage of votes received in each federal unit to compare different electoral contexts. However, since the electoral quotient serves as a barrier to representation, different values could have similar meanings. For example, whereas in São Paulo $1.43 \%$ of the valid votes is enough to meet the electoral quotient, a candidate in Rondônia needs $12.5 \%$. In the 2018 elections, the most popular candidates in São Paulo and the Federal District gained $8 \%$ and $11 \%$ of the valid votes, respectively, which would indicate that these are candidates with close political similarities. In the case of São Paulo, however, this number of votes represented over five times the electoral quotient; while in the Federal District, the value did not even make it over the electoral quotient threshold.
} 
this means from this point forward, when we mention votes, we will be talking about the relationship between candidates' votes and the electoral quotient in their FUs. In view of the asymmetric distribution of this variable (Appendix 01), we use its natural logarithm in all subsequent analysis.

The Higher Electoral Court (hereinafter, 'TSE') database differentiates between four types of candidates. 'Elected by PQ (Party Quotient)' refers to successfully elected candidates who occupy vacancies that are assigned to the parties through the first distribution of seats, which are allocated according each party's electoral quotient; 'elected by average' refers to elected candidates who fill the remaining vacancies; 'alternates' are unelected candidates who belong to the list of a party that passed the electoral quotient threshold; and 'unelected' refers to unsuccessful candidates whose parties did get enough votes to pass the electoral quotient threshold.

Figure 01. Boxplot of voting in proportion to the electoral quotient, by candidate type

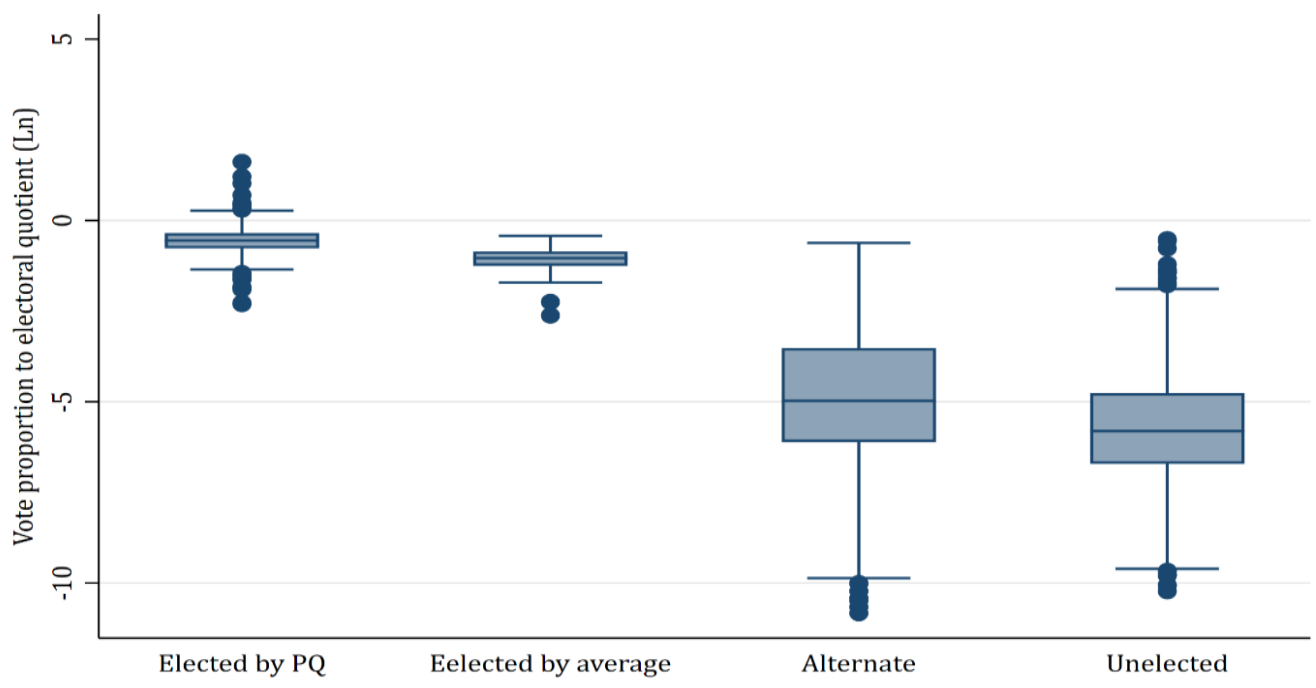

Source: Elaborated by the authors using 2018 electoral data from the TSE. Note: Key: $y$ axis = vote proportion to electoral quotient $(\mathrm{Ln}) ; x$ axis = elected by PQ, elected by average, alternate, unelected.

Elected candidates exclusively proceed from high performance candidacies. This means that elected MoCs almost entirely come from a group of just over one thousand candidates and that the other four thousand had no real chance of ever being elected, that is, they did not participate competitively in the race.

Based on the average of the variables included in a given model, linear regression is unable to accurately estimate the weight of a set of independent variables on the chances of obtaining campaign votes or resources in such an 
Race and Competitiveness in Brazilian Elections: Evaluating the Chances of NonWhite Candidates through Quantile Regression Analysis of Brazil's 2014 Congressional Elections

unequal context. To help clarify this point, let us look at the result of a linear regression that estimates the impact of candidate color/race on their vote. We would like to point out that this first model has a more didactic than analytical character. From a simplified model, it is easier to understand the potential differences between the standard linear regression model and the quantile one ${ }^{8}$.

Table 01 shows the estimated coefficients for the linear effect of color/race on voting by reference to the average vote (Model 01 ), for the quantile referring to $50 \%$ of the vote (Model 02), and for the quantile referring to $80 \%$ of the vote (Model 03). The color/race variable is a dichotomous recoding of the candidates' racial identification, in which value 01 refers to non-white candidates who, in Brazil, are classified by the census as black, brown or indigenous. From Model 01 in Table 01, where there is a linear regression explaining the variable of voting, the average number of votes for non-whites is approximately 48\%9 lower than the average number of votes for whites. In Model 02, where we have an estimated quantile regression for the vote distribution average, the same magnitude is observed $(\sim 45 \%)$. The F-test shows that there is no statistical difference between the linear model and the quantile model's estimates for vote average. However, the same model shows a significant difference in vote distribution starting with quantile 80. Votes for non-white candidates in this quantile are approximately $76 \%$ lower than for white candidates.

The relationship between color/race and votes seems to have a greater effect in the higher quantiles. It can be said that among the candidates with the most votes, being white is more important than in the case of candidates with low electoral expression. In other words, race does not matter when the chance of

\footnotetext{
${ }^{8}$ It is important to note that quantile regression is also based on a linear regression model. In a linear model, the least squares method is used to find the conditional average of the variable of interest, controlling for covariates. In a quantile regression model, the conditional quantile of the variable of interest is taken as a reference and the absolute error for each quantile is minimized (HAO and NAIMAN, 2007). For more information, see Buchinsky, M. (1998), Koenker, R. (2005), Koenker, R., and Bassett Jr, G. (1978), and Koenker, R. and K. Hallock, (2001).

${ }^{9}$ Due to the logarithmic transformation of the dependent variables used in the models presented here, the estimated coefficients in all regressions of this paper are interpreted from the following formula: exp $(\beta)$ - 1. In the specific case, $\exp (-0,651)-1=-0.478$. This means that non-white candidates receive, on average for the standard linear regression model, $47.8 \%$ fewer votes than white candidates. The coefficients estimated from the quantile model have a similar result, but the comparison reference is not the average, but the quantile specified in each model. From this point on, we present the estimates as a percentage of differences.
} 
victory does not exist but becomes relevant when the contest becomes more competitive.

Table 01. Linear regression and quantile (votes)

\begin{tabular}{lccc}
\hline & Model 01 & Model 02 & Model 03 \\
& Linear & $50 \%$ & $80 \%$ \\
\hline Color/Race & $-0.651^{* * *}$ & $-0.613^{* * *}$ & $-1.417^{* * *}$ \\
& $(0.060)$ & $(0.077)$ & $(0.138)$ \\
Constant & $-4.131^{* * *}$ & $-4.410^{* * *}$ & $-1.781^{* * *}$ \\
& $(0.040)$ & $(0.057)$ & $(0.087)$ \\
Observations ${ }^{10}$ & 5003 & 5003 & 5003 \\
$\mathrm{R}^{2} /$ Pseudo-R ${ }^{2 \dagger}$ & 0.022 & 0.010 & 0.029 \\
F-test Linear Model & & 0.694 & 0.000 \\
(Color/Race) & & & 0.000 \\
F-test Previous Quantile & & & \\
(Color/Race) & & &
\end{tabular}

Source: Elaborated by the authors using 2018 electoral data from the TSE. Note: Standard error in parenthesis $/{ }^{*} \mathrm{p}<0.05,{ }^{* *} \mathrm{p}<0.01,{ }^{* * *} \mathrm{p}<0.001$.

However, we are only evaluating the relationship between two variables here, ignoring the fact that the electoral advantages of white candidates over nonwhites may reflect other intervening variables ${ }^{10}$. With regard to social aspects, the most relevant is the unequal access to politics between men and women (ARAÚJO, 1998, 2016; ARAÚJO and ALVES, 2007; PERISSINOTTO and MIRÍADE, 2009). It is important to consider this when looking at electoral disadvantage. Non-white women are most discriminated-against group in Brazilian politics (CAMPOS and MACHADO, 2014).

Two other criteria that are consistently addressed in the literature, class and education, can also lead to specific discussions when dealing with the racial issue (HASENBALG and SILVA, 1999; RIBEIRO, 2011). There is a high concentration of individuals from the professions with high economic status and high levels of education among elected officials. The fact that racial inequalities have not been drastically reduced in history implies that, on average, whites have higher

\footnotetext{
10Perissinotto and Miríade (2009) discuss the predominant characteristics among those elected in the 2006 congressional elections based on sex, occupational class, education, age and campaign spending. All these variables except for age, were incorporated in the analytical models in this article. The non-treatment of age is due to the unobservable significant difference reported in the literature on the relationship between race and party-political performance with generational contrasts.
} 
Race and Competitiveness in Brazilian Elections: Evaluating the Chances of NonWhite Candidates through Quantile Regression Analysis of Brazil's 2014 Congressional Elections

education levels and occupational status than non-whites. The low representation of non-whites in elected office could, therefore, be explained by social lags that generate inequality in conditions of electoral competition. Controlling for the variables of class and education enables us to test if there is inequality due to candidates' color/race beyond these structural disadvantages.

In addition to the aforementioned socio-economic aspects, elements specific to electoral dynamics can help explain voting differences, such as incumbency and campaign financing. In the Brazilian literature, the discussion on incumbency focuses primarily on the explanation of what motivates MoCs to remain in their positions, and the tendency against 'progressive ambition' on their part (BARRETO, 2011; SAMUELS, 2003). The impact of incumbency on electoral chances is taken as a given, and this is confirmed by the high success rate of candidates who present themselves as professional politicians (PERISSINOTTO and MIRÍADE, 2009). Incumbents have a privileged position in relation to other candidates because they have prior political visibility and name recognition among voters, along with greater ease of raising campaign financing. As Lemos, Marcelino and Pederiva (2010, p. 376) show, candidates for reelection to the two houses of Congress raise a larger average amount of campaign funding than their challengers ${ }^{11}$. The low number of non-white MoCs, coupled with the positive effect of being an incumbent at election time, may help explain inequality between white and non-whites in national congressional competition.

Electoral funding's explanatory capacity for voting patterns is illustrated in various studies, as summarized by Mancuso (2015) ${ }^{12}$. It is worth noting that the information about campaign financing in Brazil released by the TSE presents data on both fundraising and campaign spending. There is no consensus on which of these two variables has more explanatory potential, but the small variation in effect observed by their distinct use implies a low impact on the final results of the analysis

\footnotetext{
${ }^{11}$ Jacobson (1978) says that the expenses of candidates for reelection are less impactful than those of challengers, but later studies question these findings (LEVITT, 1994), including information from Brazil (SAMUELS, 2001). For a more detailed discussion see Silva (2010 pp. 27-30).

${ }^{12}$ These findings were made by Samuels (2002); Silva (2010), Figueiredo Filho (2009), Peixoto (2010) and Figueiredo Filho et al. (2011).
} 
(MANCUSO, 2015, p. 158) ${ }^{13}$. Without disregarding this, we opted to estimate the relationship between race/color and voting based on campaign spending, as the commitment of resources to concrete actions can show differences in the ability to gain votes. In addition to these considerations, it is important to pay attention to the possible effects of other variables on spending as a predictor of voting patterns: "Endogeneity can be a problem if the expectation of a candidate's electoral performance affects the financing s/he receives. This problem can be reduced by incorporating factors such as mandate and history of public or political party employment, which are generally associated with higher electoral performance expectations" (MANCUSO, 2015, p. 174).

As this study covers the entire set of candidates, it was impossible to add information about individual characteristics such as previous performance in public office. We present both analytical models that consider financial resources and those which do not. Considering the intrinsic endogeneity of access to campaign financing, we also analyzed its relationship to race/color.

The following analysis is based on quantile models that enable us to estimate the relationship between candidates' color/race and their number of votes, controlling for factors that the cited literature identifies as relevant to electoral success (social class, education level, gender, etc). Before that, however, we need to estimate each of these independent variables' coefficients in a traditional linear regression model (Table 02). In this model, we look at the relationship of being nonwhite together with the following electorally relevant variables: 01. Sex: Female codified as value $01 ; 02$. Higher Education: Candidates with university education are classified as value $01 ; 03$. Political class: Candidates belonging to occupations classified as having a special political relationship ${ }^{14}$, are coded as 1 ;

\footnotetext{
${ }^{13}$ The following analysis will come from the data evaluated in this article that supports this view.

${ }^{14}$ This classification was based on the work of Robert Erikson, John Goldthorpe and Luciene Portocarero (1979), and is applied to Brazilian professional categories associated with politicians in Campos and Machado (2015a). Although the EGP class model is divided into seven divisions, when dealing with the social distinction that allows for reputational gains in politics, the professions that are in the two highest strata of the model were understood as high-income political classes.
} 


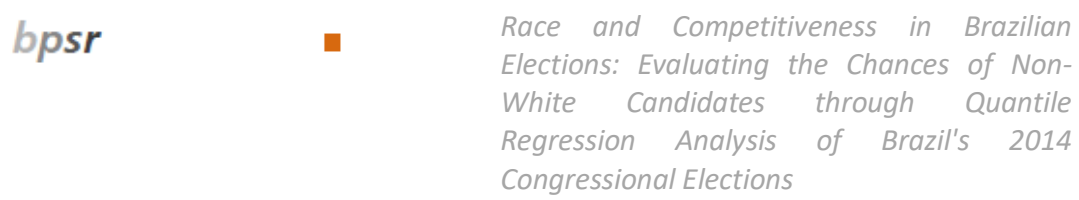

04. Incumbency: If they are running for reelection they are coded as 01 ; and 05 . Campaign spending (in natural logarithm): Campaign spending by candidate ${ }^{15}$.

As shown in Table 01, the number of votes for non-whites is, on average, lower than that for whites. The estimate of this relationship in standard linear regression models ranges from $48 \%$ to $17 \%$, according to the specifications of the model.

Table 02. Model comparison - linear regressions on campaign spending

\begin{tabular}{|c|c|c|c|c|c|c|c|}
\hline & $\begin{array}{l}\text { M01 } \\
\text { m1 }\end{array}$ & $\begin{array}{l}\text { M02 } \\
\text { m2 }\end{array}$ & $\begin{array}{l}\text { M03 } \\
\text { m3 }\end{array}$ & $\begin{array}{l}\text { M04 } \\
\text { m4 }\end{array}$ & $\begin{array}{l}\text { M05 } \\
\text { m5 }\end{array}$ & $\begin{array}{l}\text { M06 } \\
\text { m6 }\end{array}$ & $\begin{array}{l}\text { M07 } \\
\text { m7 }\end{array}$ \\
\hline Color/race & $\begin{array}{c}-0.650^{* * *} \\
(0.060)\end{array}$ & $\begin{array}{c}-0.560^{* * *} \\
(0.055)\end{array}$ & $\begin{array}{l}-0.401^{* * *} \\
(0.054)\end{array}$ & $\begin{array}{l}-0.342^{* * *} \\
(0.052)\end{array}$ & $\begin{array}{c}-0.246^{* * *} \\
(0.048)\end{array}$ & $\begin{array}{c}-0.190^{* * *} \\
(0.034)\end{array}$ & $\begin{array}{c}-0.827^{* * *} \\
(0.111)\end{array}$ \\
\hline Sex & & $\begin{array}{c}-1.779^{* * *} \\
(0.062)\end{array}$ & $\begin{array}{c}-1.715^{* * *} \\
(0.060)\end{array}$ & $\begin{array}{l}-1.538^{* * *} \\
(0.059)\end{array}$ & $\begin{array}{c}-1.384^{* * *} \\
(0.055)\end{array}$ & $\begin{array}{c}-0.864^{* * *} \\
(0.041)\end{array}$ & $\begin{array}{c}-0.863^{* * *} \\
(0.041)\end{array}$ \\
\hline $\begin{array}{l}\text { Higher } \\
\text { Education }\end{array}$ & & & $\begin{array}{l}1.029^{* * *} \\
(0.054)\end{array}$ & $\begin{array}{l}0.602^{* * *} \\
(0.058)\end{array}$ & $\begin{array}{l}0.512^{* * *} \\
(0.054)\end{array}$ & $\begin{array}{l}0.156^{* * *} \\
(0.038)\end{array}$ & $\begin{array}{l}0.161^{* * *} \\
(0.038)\end{array}$ \\
\hline Political class & & & & $\begin{array}{l}1.097^{* * *} \\
(0.058)\end{array}$ & $\begin{array}{l}0.876^{* * *} \\
(0.055)\end{array}$ & $\begin{array}{l}0.290^{* * *} \\
(0.038)\end{array}$ & $\begin{array}{l}0.292^{* * *} \\
(0.038)\end{array}$ \\
\hline Incumbency & & & & & $\begin{array}{l}3.099^{* * *} \\
(0.056)\end{array}$ & $\begin{array}{l}1.062^{* * *} \\
(0.056)\end{array}$ & $\begin{array}{l}1.025^{* * *} \\
(0.057)\end{array}$ \\
\hline $\begin{array}{l}\text { Campaign } \\
\text { spending } \\
\text { (Ln) }\end{array}$ & & & & & & $\begin{array}{l}0.537^{* * *} \\
(0.007)\end{array}$ & $\begin{array}{l}0.562^{* * *} \\
(0.008)\end{array}$ \\
\hline $\begin{array}{l}\text { Interaction of } \\
\text { color/race } \\
\text { with } \\
\text { campaign } \\
\text { spending } \\
\text { (Ln) }\end{array}$ & & & & & & & $-0.076^{* * *}$ \\
\hline Constant & $\begin{array}{c}-4.137^{* * *} \\
(0.040)\end{array}$ & $\begin{array}{c}-3.677^{* * *} \\
(0.040)\end{array}$ & $\begin{array}{c}-4.428^{* * *} \\
(0.054)\end{array}$ & $\begin{array}{c}-4.897^{* * *} \\
(0.054)\end{array}$ & $\begin{array}{c}-4.994^{* * *} \\
(0.051)\end{array}$ & $\begin{array}{l}-0.006 \\
(0.077)\end{array}$ & $\begin{array}{c}0.200^{*} \\
(0.082)\end{array}$ \\
\hline Observations & 5021 & 5021 & 5021 & 5021 & 5021 & 5021 & 5021 \\
\hline $\mathrm{R}^{2}$ & 0.022 & 0.160 & 0.211 & 0.262 & 0.390 & 0.719 & 0.721 \\
\hline
\end{tabular}

Source: Elaborated by the authors using 2018 electoral data from the TSE.

Note: Standard error in parenthesis $/{ }^{*} \mathrm{p}<0.05,{ }^{* *} \mathrm{p}<0.01,{ }^{* * *} \mathrm{p}<0.001$.

The introduction of control by socioeconomic variables (higher education and class) shows that part of racial inequality is linked to the difficulties of access to social positions that have greater political benefits (Table 02, Models 03 and 04).

\footnotetext{
15In order to allow interpretation, the percentage equivalent to campaign funding was calculated in relation to the sum of the total campaign funding accumulated by all candidates in the electoral district, and the natural log was calculated based on the distribution.
} 
Incumbency and campaign spending variables (Models 05, 06, and 07) also affect the relationship between race/color and votes. The issue of campaign financing, however, strongly affects the relationship between all variables. Understanding funding distribution patterns is, therefore, of key importance in understanding electoral dynamics. In Models 05 and 06, which jointly consider the effects of sex, education level, class, incumbency and campaign spending, the average number of votes for non-white candidates is approximately $22 \%$ and $17 \%$ lower, respectively, than the overall average number of votes for whites. This demonstrates that even when controlling for these other variables there is still a causal relationship between non-white status and number of votes.

Given the impact of campaign spending on the model's explanatory capacity, however, it is important to examine whether there is a difference between whites and non-whites related to the effects of campaign spending. The interaction between race/color and spending, presented in Model 07, shows that increased campaign investment produces a lower return for non-white candidates than it does for white candidates. For example, while increased campaign spending by white candidates produces gains of $0.56 \%$ in votes per $1 \%$ spending increase, nonwhite candidates show a lower ratio of approximately $0.49 \%$ per $1 \%$ spending increase.

The largest adjusted R2 is that of Model 07, which is the model that shows the greatest causal relationship. However, it is hard to isolate campaign spending as an independent variable from voting potential and other candidate characteristics such as race/color. More promising electoral candidates tend to be more likely to obtain campaign financing, which may lead to the endogeneity problems previously pointed out by Mancuso (2015). Thus, we have chosen to address this with two models: one that does not consider financial resources, Model 05, and one that does, Model 07, since there is a possibility of bias in the estimates depending on whether financing-related information is included.

\section{Quantile regression}

We will now examine how these coefficients behave in the different voting quantiles. For this, we present the linear and quantile regression in Table 
03, factoring in the specifications of Model $05^{16}$ in Table 02, with the respective coefficients of the variables of sex, education, class and incumbency.

Table 03. Comparison of linear and quantile regressions - Model 05 without campaign spending

\begin{tabular}{|c|c|c|c|c|c|c|}
\hline & M01 & M02 & M03 & M04 & M05 & M06 \\
\hline & Linear & $50 \%$ & $60 \%$ & $70 \%$ & $80 \%$ & $90 \%$ \\
\hline \multirow{2}{*}{ Color/race } & $-0.244^{* * *}$ & $-0.210^{* * *}$ & $-0.263^{* * *}$ & $-0.288^{* * *}$ & $-0.350^{* * *}$ & $-0.507^{* * *}$ \\
\hline & $(0.048)$ & $(0.048)$ & $(0.056)$ & $(0.067)$ & $(0.080)$ & $(0.088)$ \\
\hline \multirow{2}{*}{ Sex } & $-1.382^{* * *}$ & $-1.330^{* * *}$ & $-1.360^{* * *}$ & $-1.440^{* * *}$ & $-1.371^{* * *}$ & $-1.329^{* * *}$ \\
\hline & $(0.056)$ & $(0.057)$ & $(0.060)$ & $(0.074)$ & $(0.097)$ & $(0.119)$ \\
\hline \multirow{2}{*}{ Higher Education } & $0.512^{* * *}$ & $0.456^{* * *}$ & $0.514^{* * *}$ & $0.615^{* * *}$ & $0.640^{* * *}$ & $0.814^{* * *}$ \\
\hline & $(0.054)$ & $(0.054)$ & $(0.063)$ & $(0.072)$ & $(0.086)$ & $(0.111)$ \\
\hline \multirow{2}{*}{ Political Class } & $0.874^{* * *}$ & $0.831^{* * *}$ & $0.980^{* * *}$ & $1.109^{* * *}$ & $1.319^{* * *}$ & $1.214^{* * *}$ \\
\hline & $(0.055)$ & $(0.055)$ & $(0.073)$ & $(0.073)$ & $(0.092)$ & $(0.113)$ \\
\hline \multirow{2}{*}{ Incumbency } & $3.097^{* * *}$ & $3.261^{* * *}$ & $2.837^{* * *}$ & $2.402^{* * *}$ & $1.954^{* * *}$ & $1.510^{* * *}$ \\
\hline & $(0.056)$ & $(0.043)$ & $(0.065)$ & $(0.077)$ & $(0.095)$ & $(0.110)$ \\
\hline \multirow{2}{*}{ Constant } & $-4.991^{* * *}$ & $-5.090^{* * *}$ & $-4.759^{* * *}$ & $-4.320^{* * *}$ & $-3.829^{* * *}$ & $-2.883^{* * *}$ \\
\hline & $(0.051)$ & $(0.052)$ & $(0.062)$ & $(0.069)$ & $(0.087)$ & $(0.121)$ \\
\hline Observations & 5003 & 5003 & 5003 & 5003 & 5003 & 5003 \\
\hline $\mathrm{R}^{2} /$ Pseudo- $\mathrm{R}^{2} \dagger$ & 0.390 & 0.247 & 0.258 & 0.265 & 0.255 & 0.204 \\
\hline $\begin{array}{l}\text { F-test Linear Model } \\
\text { (Color/Race) }\end{array}$ & & 0.622 & 0.795 & 0.594 & 0.255 & 0.009 \\
\hline $\begin{array}{l}\text { F-test Previous } \\
\text { Quantile (Color/Race) }\end{array}$ & & & 0.060 & 0.489 & 0.144 & 0.039 \\
\hline
\end{tabular}

Source: Elaborated by the authors using 2018 electoral data from the TSE.

Note: Standard error in parenthesis $/{ }^{*} \mathrm{p}<0.05,{ }^{* *} \mathrm{p}<0.01,{ }^{* * *} \mathrm{p}<0.001$.

The linear regression estimate of the relationship between race/color and votes is not statistically different from quantile models up to 80 . However, the $90 \%$ quantile estimate shows that non-white candidates are significantly more disadvantaged when they are most likely to be successful. While the linear model estimates approximately $22 \%$ less votes for non-white candidacies overall, in the $90 \%$ quantile the relationship appears to cause a $40 \%$ drop.

\footnotetext{
${ }^{16}$ In order to allow interpretation, the percentage equivalent to campaign funding was calculated in relation to the sum of the total campaign funding accumulated by all candidates in the electoral district, and the natural log was calculated based on the distribution.
} 
Figure 02 visually demonstrates this difference, showing both methods' estimated coefficients and confidence intervals. The green curve represents the value estimated by the quantile regression for each point, in 0.5-point increments, between the 10 and 95 quantiles. The gray area represents the estimated confidence interval for the parameters of each quantile. The center line is the value estimated by linear regression associated with the $90 \%$ confidence interval.

Figure 02. Race/color estimates in relation to votes gained, based on model 05 without campaign spending - linear and quantiles 10-95 in 0.5 Percentage point increments

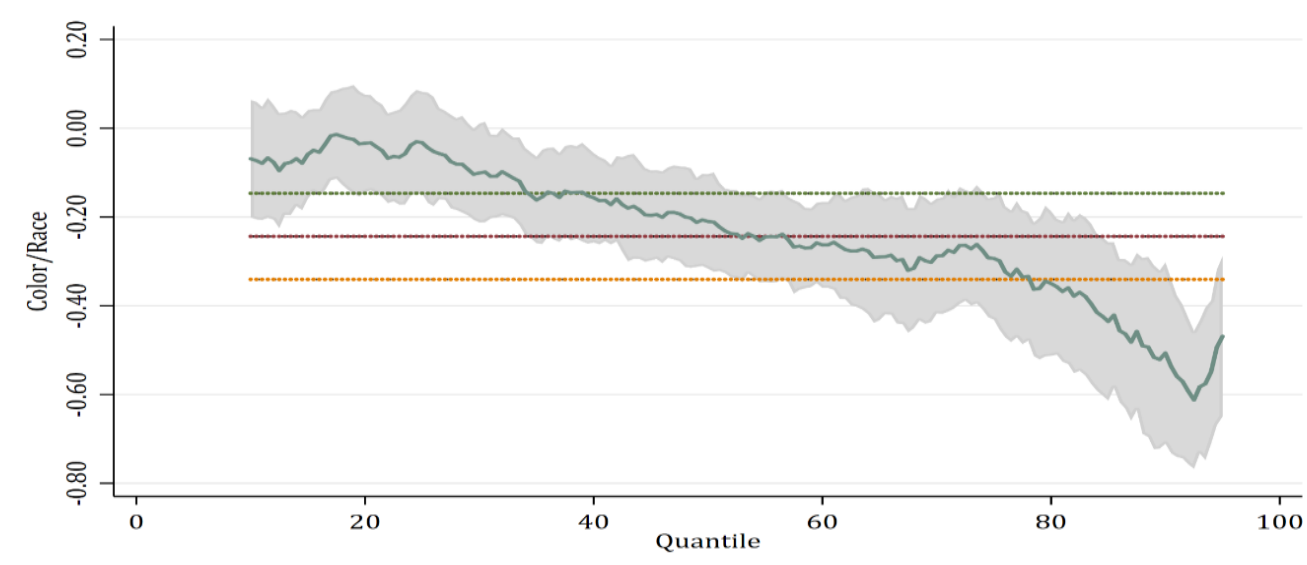

Source: Elaborated by the authors using 2018 electoral data from the TSE (2018). Note: Key: $y$-axis = color $/$ race; $x$-axis = quantile.

The variable with the greatest effect on votes is incumbency, the rate of which tends to fall as we move down through the distribution quantiles. This relationship raises a question that needs further investigation. Although the statistical model calculates the effect of incumbency in each of the quantiles, it is important to consider that these cases are concentrated in the highest cuts. Only one case is observed in the $10 \%$ decile with the rest located above $75 \%$. That is, the most robust variable of incumbency cannot be used in the initial distribution quantiles because it does not exist there. This implies that the linear regression coefficient should be viewed with caution, because when we look at the distribution effect in quantiles in which incumbent candidates actually exist, there is a relevant reduction, such as in the $95 \%$ quantile, where incumbency guarantees over 70\% more votes than other candidates.

As expected, controlling the relationship between candidate votes and racial profile reduces the impact of being non-white, taking into consideration that part of the electoral inequality linked to this characteristic is due to specific conditions that are more prevalent among non-white candidates, including the fact that fewer non- 
whites have access to higher education or professions with high political status. However, it is important to ask what specific effect these other variables have on non-white candidates. As shown in Table 02, a significant part of voting is explained by campaign financing, so it is important to identify if this effect varies within the distribution of votes. In Table 04, we compare the linear model with the quantile model, including the variable of campaign spending.

Table 04. Linear and quantile regression comparison - model 07 with campaign spending

\begin{tabular}{|c|c|c|c|c|c|c|}
\hline & M01 & M02 & M03 & M04 & M05 & M06 \\
\hline & Linear & $50 \%$ & $60 \%$ & $70 \%$ & $80 \%$ & $90 \%$ \\
\hline \multirow{2}{*}{ Color/race } & $-0.827^{* * *}$ & $-0.789^{* * *}$ & $-0.787^{* * *}$ & $-0.690^{* * *}$ & $-0.566^{* * *}$ & $-0.583^{* * *}$ \\
\hline & $(0.111)$ & $(0.127)$ & $(0.128)$ & $(0.129)$ & $(0.145)$ & $(0.170)$ \\
\hline \multirow{2}{*}{ Sex } & $-0.863^{* * *}$ & $-0.851^{* * *}$ & $-0.785^{* * *}$ & $-0.685^{* * *}$ & $-0.610^{* * *}$ & $-0.558^{* * *}$ \\
\hline & $(0.041)$ & $(0.049)$ & $(0.051)$ & $(0.049)$ & $(0.056)$ & $(0.062)$ \\
\hline \multirow{2}{*}{ Higher Education } & $0.161^{* * *}$ & $0.123^{* *}$ & $0.164^{* * *}$ & $0.139^{* *}$ & $0.124^{* *}$ & $0.133^{*}$ \\
\hline & $(0.038)$ & $(0.045)$ & $(0.043)$ & $(0.047)$ & $(0.048)$ & $(0.061)$ \\
\hline \multirow{2}{*}{ Political Class } & $0.292^{* * *}$ & $0.271^{* * *}$ & $0.285^{* * *}$ & $0.298^{* * *}$ & $0.290^{* * *}$ & $0.321^{* * *}$ \\
\hline & $(0.038)$ & $(0.046)$ & $(0.045)$ & $(0.043)$ & $(0.050)$ & $(0.061)$ \\
\hline \multirow{2}{*}{ Incumbency } & $1.025^{* * *}$ & $0.873^{* * *}$ & $0.735^{* * *}$ & $0.701^{* * *}$ & $0.704^{* * *}$ & $0.673^{* * *}$ \\
\hline & $(0.057)$ & $(0.061)$ & $(0.057)$ & $(0.065)$ & (0.087) & $(0.092)$ \\
\hline \multirow{2}{*}{$\begin{array}{l}\text { Campaign } \\
\text { spending (Ln) }\end{array}$} & $0.562^{* * *}$ & $0.576^{* * *}$ & $0.578^{* * *}$ & $0.577^{* * *}$ & $0.568^{* * *}$ & $0.551^{* * *}$ \\
\hline & $(0.008)$ & $(0.010)$ & (0.009) & $(0.009)$ & $(0.010)$ & $(0.013)$ \\
\hline $\begin{array}{l}\text { Interaction of } \\
\text { Color/Race and }\end{array}$ & $-0.076^{* * *}$ & $-0.071^{* * *}$ & $-0.074^{* * *}$ & $-0.064^{* * *}$ & $-0.055^{* *}$ & $-0.058^{* *}$ \\
\hline $\begin{array}{l}\text { Campaign } \\
\text { Spending (Ln) }\end{array}$ & $(0.013)$ & $(0.015)$ & $(0.015)$ & $(0.015)$ & $(0.017)$ & $(0.020)$ \\
\hline \multirow{2}{*}{ Constant } & $0.200^{*}$ & $0.397^{* * *}$ & $0.630^{* * *}$ & $0.878^{* * *}$ & $1.124^{* * *}$ & $1.414^{* * *}$ \\
\hline & $(0.082)$ & $(0.099)$ & $(0.092)$ & $(0.092)$ & (0.101) & $(0.129)$ \\
\hline Observation & 5021 & 5021 & 5021 & 5021 & 5021 & 5021 \\
\hline $\mathrm{R}^{2} /$ Pseudo- $\mathrm{R}^{2} \dagger$ & 0.721 & 0.491 & 0.513 & 0.530 & 0.535 & 0.504 \\
\hline $\begin{array}{l}\text { F-test Linear } \\
\text { Model } \\
\text { (Color/Race) }\end{array}$ & & 0.819 & 0.815 & 0.420 & 0.154 & 0.228 \\
\hline $\begin{array}{l}\text { F-test Previous } \\
\text { Quantile } \\
\text { (Color/Race) }\end{array}$ & & & 0.990 & 0.346 & 0.198 & 0.862 \\
\hline
\end{tabular}

Source: Elaborated by the authors using 2018 electoral data from the TSE.

Note: Standard error in parenthesis / ${ }^{*} \mathrm{p}<0.05,{ }^{* *} \mathrm{p}<0.01,{ }^{* * *} \mathrm{p}<0.001$. 
In the models that include campaign spending, we observe that there is almost no difference between the estimates of race/color coefficients from quantile models in relation to the linear regression model. The $\mathrm{F}$ tests show that there is no statistical significance between the different quantile models themselves and between them and the linear model. Figure 03 shows this visually.

If the negative effects of the variables of race/color, and gender diminish in the higher quantiles, this is due to greater access to campaign financing for these more competitive nonwhites and women. As discussed earlier, the relationship between incumbency and votes gradually reduces. The linear model estimates an over $100 \%$ vote gain for incumbent candidates, while in the quantile regression model the impact at the 90 quantile is approximately 95\% more votes compared to challenger candidates.

Figure 03. Estimates of the relationship between race/color and votes, using Model 07 with campaign expenses - linear regression and quantiles from 10 to 95 with 0.5point increments

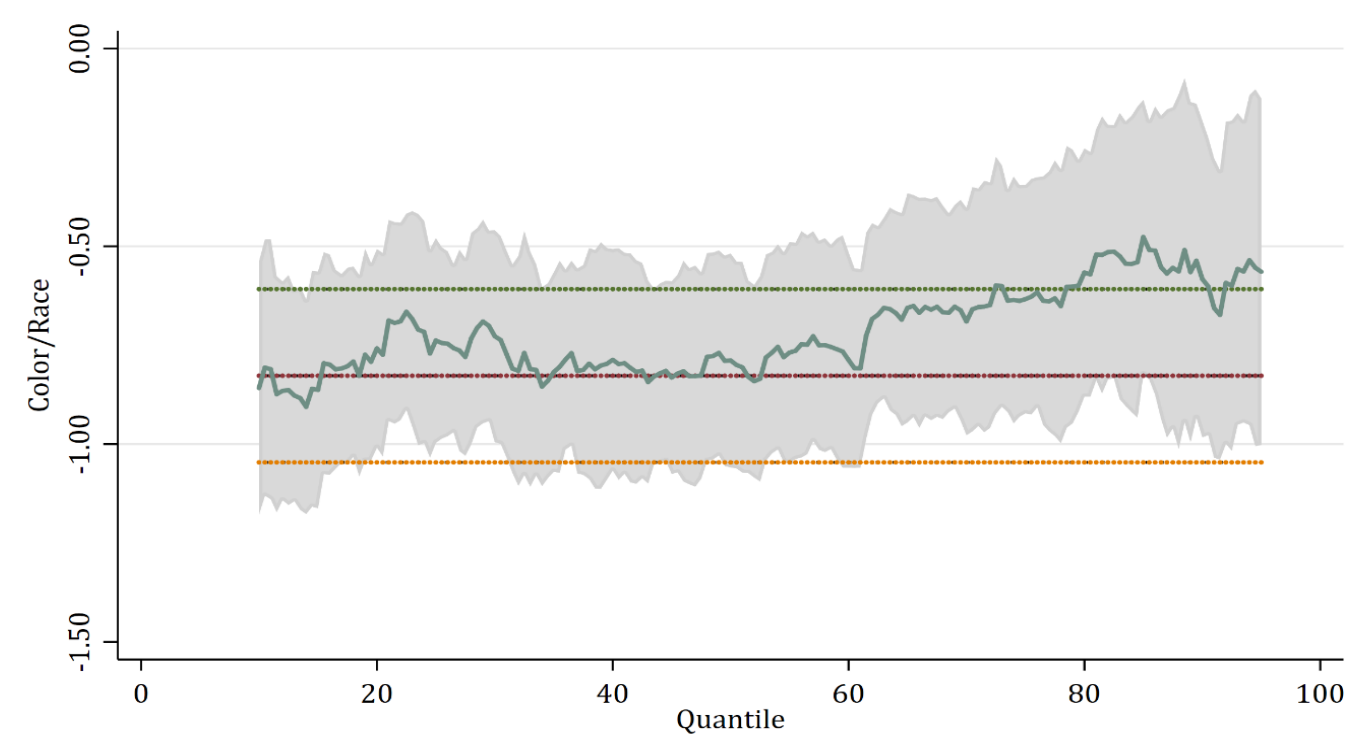

Source: Elaborated by the authors using 2018 electoral data from the TSE. Note: Key: $y$ axis = color $/$ race; $x$ axis = quantile.

However, due to possible endogeneity problems caused by adding campaign spending to the model, we have to explain the campaign funding distribution. On the one hand, the effect of campaign spending on voting shows the need to explain the constraints related to access to campaign funding. On the other, the issue of 
endogeneity provides an important justification for looking at campaign financing as a dependent variable. This is depicted from Table 05.

We will now look at campaign fundraising instead of campaign spending as a dependent variable, because the effect of financing that we aim to explain is the difference in the profiles of candidates who receive unequal funding for their campaigns. Variation in campaign spending is related to this, but it depends on other factors, such as campaign strategies ${ }^{17}$, the perception of real chance of victory ${ }^{18}$ and specific electoral conditions in each district. Although revenues and expenses have similar results, confirmed by Mancuso (2015) in the comparison between Table 05 and Table A2 in the Annex, the above argument provides a theoretical basis for designating campaign fundraising as a dependent variable.

As in the case of campaign spending, the campaign fundraising indicator was calculated as a proportion of the total revenue declared in the electoral district, to enable comparison between different contexts of the elections. The variable was also transformed into a natural log, in view of its distribution (Figures A6 and A7 in the Annex). As in the case of vote distribution, elected candidates concentrate at the top in terms of campaign fundraising distribution, as shown in Figure 04.

Figure 04. Boxplot of campaign fundraising, by candidate's situation

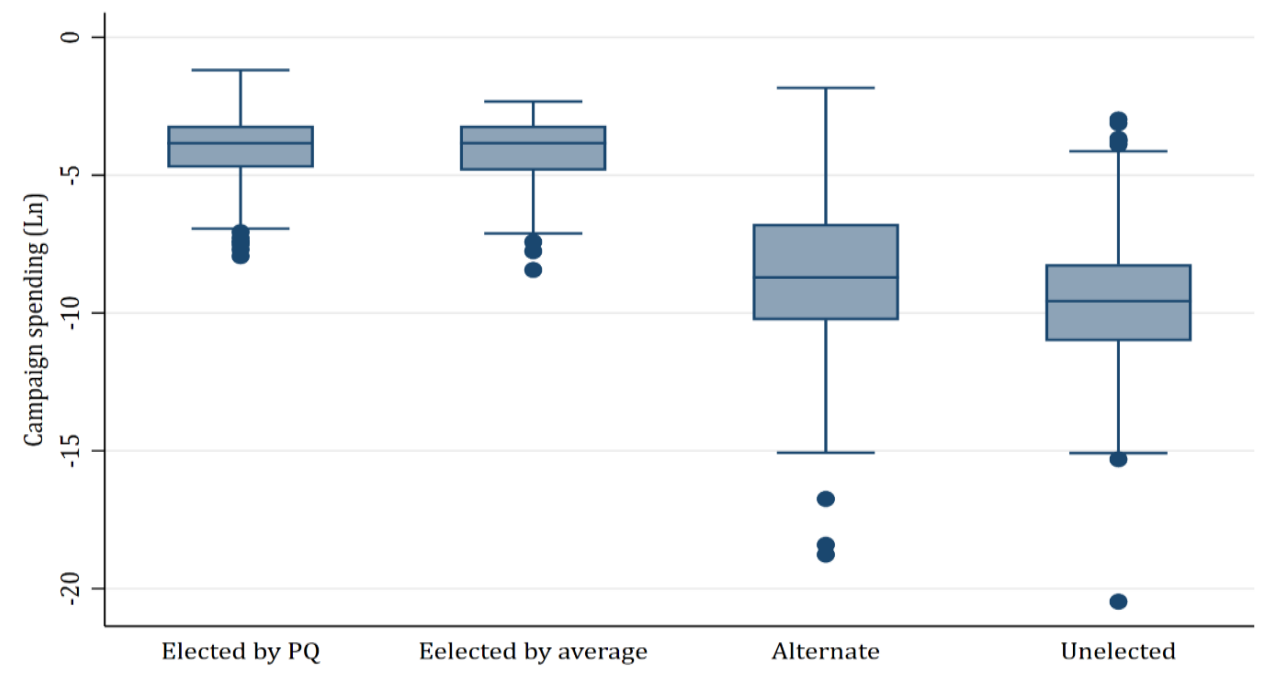

Source: Elaborated by the authors using 2018 electoral data from the TSE.

Note: Key: $y$ axis = campaign spending (Ln); $x$ axis = elected by PQ, elected by average, alternate, unelected.

17Bruno Speck and Emerson Cervi (2016) identify different campaign strategies used by mayoral candidates depending on size of city, while Nelson Rojas de Carvalho (2003) identifies different patterns of territorial distribution of voting among federal congressional candidates.

18Wescrey Portes Pereira (2018) notes in his case studies that unelected candidacies tend not to spend the total amount of funds raised while elected candidates tend to spend the full amount on their campaigns. 
The comparison of linear models specifications in Table 05 shows that Model 05 has the highest explanatory capacity. It is important to note here that the estimate of the effect of race is reduced to the point of losing statistical significance when it is controlled by these socioeconomic and political variables.

Table 05. Comparison of models - income dependent linear regressions

\begin{tabular}{lccccc}
\hline & M01 & M02 & M03 & M04 & M05 \\
& $\mathrm{m} 1$ & $\mathrm{~m} 2$ & $\mathrm{~m} 3$ & $\mathrm{~m} 4$ & $\mathrm{~m} 5$ \\
\hline \multirow{2}{*}{ Color/Race } & $-0.571^{* * *}$ & $-0.496^{* * *}$ & $-0.292^{* * *}$ & $-0.218^{* *}$ & -0.102 \\
& $(0.076)$ & $(0.074)$ & $(0.073)$ & $(0.071)$ & $(0.067)$ \\
Sex & & $-1.459^{* * *}$ & $-1.376^{* * *}$ & $-1.156^{* * *}$ & $-0.969^{* * *}$ \\
& & $(0.079)$ & $(0.077)$ & $(0.077)$ & $(0.073)$ \\
Higher Education & & & $1.307^{* * *}$ & $0.779^{* * *}$ & $0.670^{* * *}$ \\
& & & $(0.073)$ & $(0.078)$ & $(0.074)$ \\
Political Class & & & & $1.351^{* * *}$ & $1.080^{* * *}$ \\
& & & & $(0.078)$ & $(0.076)$ \\
Incumbency & & & & & $3.785^{* * *}$ \\
Constant & $-8.003^{* * *}$ & $-7.627^{* * *}$ & $-8.584^{* * *}$ & $-9.161^{* * *}$ & $-9.079)$ \\
Observations & $(0.051)$ & $(0.054)$ & $(0.073)$ & $(0.075)$ & $(0.072)$ \\
$\mathrm{R}^{2}$ & 5003 & 5003 & 5003 & 5003 & 5003 \\
\hline
\end{tabular}

Source: the authors using 2018 electoral data from the TSE.

Note: Standard error in parenthesis $/{ }^{*} \mathrm{p}<0.05,{ }^{* *} \mathrm{p}<0.01,{ }^{* * *} \mathrm{p}<0.001$.

When using the quantile regression model (Table 06) to explain campaign fundraising, the variation between the quantiles is statistically significant from the $80 \%$ quantile cut forwards, as can be seen by the $\mathrm{F}$ test against the previous quantile. If the estimated effect of race on linear regression is not initially statistically significant, showing that non-whites have a 09\% disadvantage in campaign funding, by the 90 quantile this disadvantage reaches 35\%. We emphasize that there is statistical significance from the 80 quantile forward - marginally in the case of the 80 quantile - between the linear estimate and the estimates from the quantile models.

The estimated effect of gender remains constant among all quantiles, while higher education and political class have a stronger effect on the strata with the highest concentration of campaign financing. As in the case of votes, the estimate effect of incumbency shows a considerable downward trend with campaign funding distribution. 
Table 06. Campaign fundraising linear and quantile regression comparison

\begin{tabular}{|c|c|c|c|c|c|c|}
\hline & $\begin{array}{c}\text { M01 } \\
\text { Linear }\end{array}$ & $\begin{array}{l}\text { M02 } \\
50 \%\end{array}$ & $\begin{array}{l}\text { M03 } \\
60 \%\end{array}$ & $\begin{array}{l}\text { M04 } \\
70 \%\end{array}$ & $\begin{array}{l}\text { M05 } \\
80 \%\end{array}$ & $\begin{array}{l}\text { M06 } \\
90 \%\end{array}$ \\
\hline \multirow{2}{*}{ Color/Race } & -0.102 & -0.040 & -0.065 & -0.064 & $-0.307^{* *}$ & $-0.427^{* * *}$ \\
\hline & $(0.067)$ & $(0.077)$ & $(0.082)$ & $(0.091)$ & $(0.104)$ & $(0.110)$ \\
\hline \multirow{2}{*}{ Sex } & $-0.969^{* * *}$ & $-0.898^{* * *}$ & $-1.005^{* * *}$ & $-1.066^{* * *}$ & $-1.108^{* * *}$ & $-1.058^{* * *}$ \\
\hline & $(0.073)$ & $(0.083)$ & $(0.089)$ & $(0.103)$ & $(0.116)$ & $(0.135)$ \\
\hline \multirow{2}{*}{ Higher Education } & $0.670^{* * *}$ & $0.665^{* * *}$ & $0.690^{* * *}$ & $0.840^{* * *}$ & $0.853^{* * *}$ & $0.950^{* * *}$ \\
\hline & $(0.074)$ & $(0.085)$ & $(0.086)$ & $(0.101)$ & $(0.119)$ & $(0.117)$ \\
\hline \multirow{2}{*}{ Political Class } & $1.080^{* * *}$ & $1.138^{* * *}$ & $1.296^{* * *}$ & $1.423^{* * *}$ & $1.460^{* * *}$ & $1.557^{* * *}$ \\
\hline & $(0.076)$ & $(0.089)$ & $(0.089)$ & $(0.104)$ & $(0.119)$ & $(0.143)$ \\
\hline \multirow{2}{*}{ Incumbency } & $3.785^{* * *}$ & $4.031^{* * *}$ & $3.491^{* * *}$ & $3.027^{* * *}$ & $2.420^{* * *}$ & $1.844^{* * *}$ \\
\hline & $(0.079)$ & $(0.078)$ & $(0.078)$ & $(0.096)$ & $(0.113)$ & $(0.117)$ \\
\hline \multirow{2}{*}{ Constant } & $-9.280^{* * *}$ & $-9.491^{* * *}$ & $-8.893^{* * *}$ & $-8.388^{* * *}$ & $-7.474^{* * *}$ & $-6.410^{* * *}$ \\
\hline & $(0.072)$ & $(0.079)$ & $(0.079)$ & $(0.100)$ & $(0.119)$ & $(0.143)$ \\
\hline Observations & 5003 & 5003 & 5003 & 5003 & 5003 & 5003 \\
\hline $\mathrm{R}^{2} /$ Pseudo- $\mathrm{R}^{2} \dagger$ & 0.287 & 0.180 & 0.193 & 0.202 & 0.202 & 0.173 \\
\hline $\begin{array}{l}\text { F-test Linear } \\
\text { Model } \\
\text { (Color/Race) }\end{array}$ & & 0.546 & 0.726 & 0.737 & 0.097 & 0.011 \\
\hline $\begin{array}{l}\text { F-test Previous } \\
\text { Quantile } \\
\text { (Color/Race) }\end{array}$ & & & 0.662 & 0.990 & 0.001 & 0.113 \\
\hline
\end{tabular}

Source: Elaborated by the authors using 2018 electoral data from the TSE.

Notes: Standard error in parenthesis $/{ }^{*} \mathrm{p}<0.05,{ }^{* *} \mathrm{p}<0.01,{ }^{* * *} \mathrm{p}<0.001$.

Returning to the analysis of the effect of race on campaign fundraising, Figure 05 shows how there is either no statistically relevant difference between non-whites and whites in the lower funding strata or there is a slight tendency of advantage for non-white candidates. However, this relationship becomes a clear disadvantage for non-white candidates from quantile 70 of the financing distribution forwards, leading to significantly greater inequality between whites and non-whites in the funding range above $90 \%$ of the distribution.

In the higher levels of voting and campaign funding, where competition practically dissipates and shows signs of confirmation of favorites in their respective constituencies, a more qualitative analysis is needed to understand better the stories behind these campaigns ${ }^{19}$. Other crucial variables could be looked

${ }^{19}$ There is a central point in recent political dynamics that contradicts the present analysis due to lack of information, but in the last elections there is a growing perceived effect of family-connected candidacies being elected, which would certainly help clarify the distinction among the most votedfor candidates. 
at, such as the amount of free commercial airtime allocated to each candidate, political experience, professional experience, or belonging to a politically connected family.

Figure 05. Estimates of race/color in relation to campaign revenue, starting from Model 05 - linear and quantiles $10-95$ with increments of 0.5 points

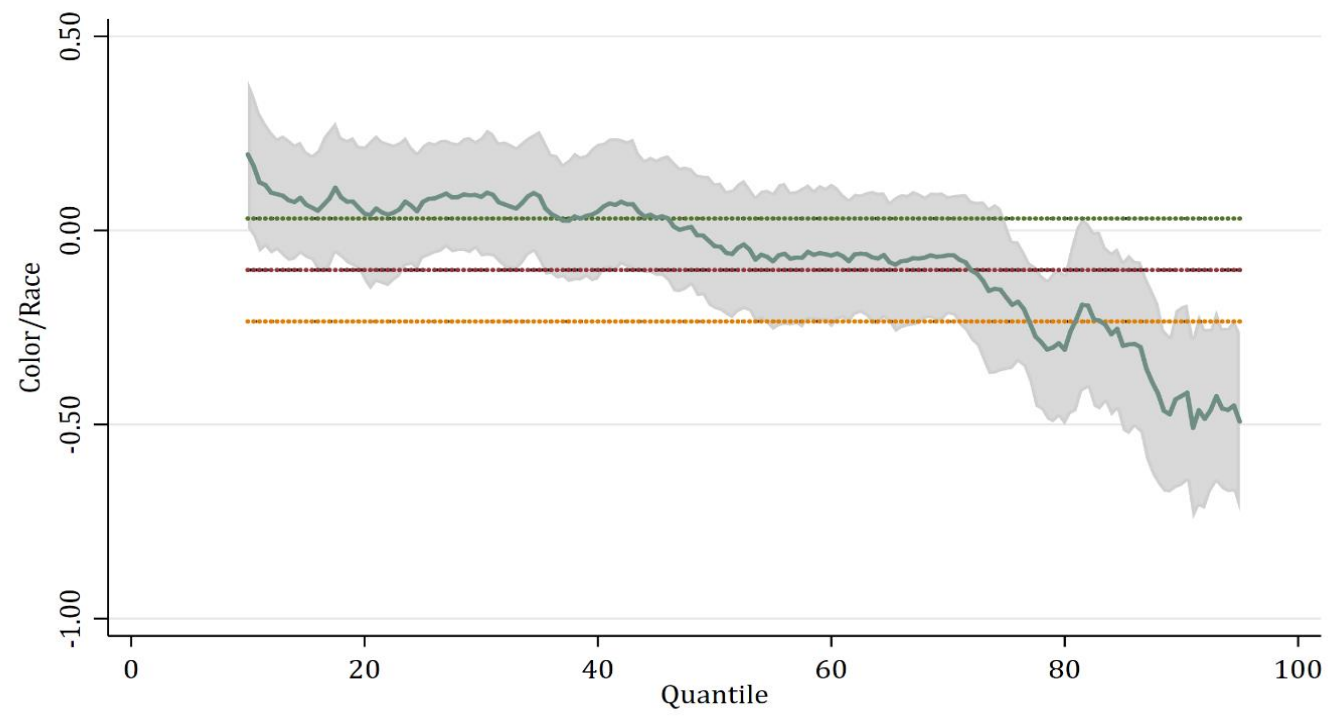

Source: Elaborated by the authors using 2018 electoral data from the TSE.

Note: Key: $y$ axis = color $/$ race; $x$ axis = quantile.

Nevertheless, the above data can be used to clarify an important question related to elections and race. The low electoral representation of the non-white population cannot be simply attributed to the material inequality in Brazilian society. Neither education nor profession are enough to explain the lower levels of voting for non-whites, because even when these variables are used to control the racial effect on electoral dynamics, non-white status persists as a vote reducing factor. It is important to emphasize that this effect is even more pronounced when analyzing black women candidates in the electoral context.

\section{Conclusions}

The structure of Brazilian electoral competition, which combines proportional representation, open lists and the distribution of seats by electoral quotient, poses specific challenges to the analysis of factors that affect the success of certain types of candidates. Most analytical models for elections measure electoral success either as obtaining legislative seats or as obtaining large amounts of votes (SPECK and CERVI, 2016, p. 60). In majority or proportional closed-list systems, a 
Race and Competitiveness in Brazilian

Elections: Evaluating the Chances of NonWhite Candidates through Quantile Regression Analysis of Brazil's 2014 Congressional Elections

logistic or linear regression model is sufficient to explain such success, as competitive candidacies can be measured by the principle, observed by Gary Cox (1997), that the chances of competing for office are distributed to the candidates with the most votes, equivalent to the number of seats plus one. In these cases, in single-round electoral disputes with a single winner, only the two leading candidates in opinion polls are effectively competing.

This does not perfectly apply to the Brazilian system, however. Despite the possibility of deducing the number of votes obtained by the most competitive candidates (CAMPOS and MACHADO, 2015a) this is an 'a posteriori' measurement. The open list system employs a voting gradient to create an electoral quotient that must be taken into account. Quantile regression partially overcomes this challenge by enabling estimates of the effects of certain variables on candidacies distributed on a voting continuum. If we view funding as a way of expressing the ability to mobilize political support, the model can be useful by analyzing candidate campaign revenue.

Without understanding the characteristics of our electoral system and its political differentiation and distinction among candidates, it is impossible to understand racial inequality in Brazilian politics. The projection of society's existing inequalities into politics is mediated by electoral rules and a complex set of sociopolitical dynamics. The data presented show that once the barriers of first access to political representation are overcome, social inequalities between white and non-white people are significantly reduced. At the same time, it is insufficient to simplify these inequalities to one dimension. Both gender and race have specific effects on the success of political careers. Moreover, the intersection between these two variables creates a situation that cannot be summed up simply by summing the two cleavages.

In general, racial inequalities in access to political representation are fundamentally rooted in difficulties obtaining equal campaign funding. Therefore, it is crucial to discuss the issue of access to campaign funding, highlighting the importance how political parties choose which candidacies to focus their resources on. We need more dialogue on how political parties' internal practices foster favors and privileges for certain traditional groups, mostly whites. The battle for social spaces for the non-white population in Brazil cannot advance without serious 
discussions about access to the public sphere, and the debate cannot view the inclusion of non-white women, who are the main victims of exclusion from public life in Brazil's so-called 'paradise of three races', as a subordinate theme.

Translated by Fraser Robinson

Submitted on May 06, 2018

Accepted on March 15, 2019

\section{References}

ADAMS, John (1856), The works of John Adams. Vol. 04. Boston: Little, Brown and Co.

ARAÚJO, Clara M. O. (2016), Valores e desigualdades de gênero: mediações entre participação política e representação democrática. Civitas: Revista de Ciências Sociais. Vol. 16, № 02, pp. 36-61.

ARAÚJO, Clara M. O. (1998), Mulheres e representação política - a experiência das cotas no Brasil. Revista Estudos Feministas. Vol. 06, № 01, pp. 71-90.

ARAUJO, Clara M. O. and ALVES, José Eustáquio Diniz (2007), Impactos de indicadores sociais e do sistema eleitoral sobre as chances das mulheres nas eleições e suas interações com as cotas. Dados. Vol. 50, № 03, pp. 535-577.

BARRETO, Alvaro Augusto de Borba (2011), Reeleição para a Câmara dos Deputados brasileira em 2006 e as incertezas do sistema eleitoral. Política \& Sociedade. Vol. 10, № 19, pp. 167-198.

BOLOGNESI, Bruno; PERISSINOTTO, Renato Monseff, and CODATO, Adriano (2016), Reclutamiento político en Brasil. Mujeres, negros y partidos en las elecciones federales de 2014. Revista Mexicana de Ciencias Políticas y Sociales. Vol. 61, № 226, pp. 247-278.

BUCHINSKY, Moshe (1998), Recent advances in quantile regression models: a practical guideline for empirical research. The Journal of Human Resources. Vol. 33, № 01, pp. 88-126.

BUENO, Natália and DUNNING, Thad (2013), Race, resources, and representation: evidence from Brazilian politicians. World Politics. Vol. 69, № 02, pp. 327-365.

CARVALHO, Nelson Rojas de (2003), E no início eram as bases: geografia política do voto e comportamento legislativo no Brasil. Rio de Janeiro: Editora Revan. 224 pp..

CAMPOS, Luiz Augusto and MACHADO, Carlos (2015a), A cor dos eleitos: determinantes da sub-representação política dos não-brancos no Brasil. Revista Brasileira de Ciência Política. № 16, pp. 121-151. 
CAMPOS, Luiz Augusto and MACHADO, Carlos (2015b), A raça dos (in)eleitos. Insight Inteligência. Vol. 17, № 67, pp. 60-72.

CAMPOS, Luiz Augusto and MACHADO, Carlos (2014), A cor e o sexo da política: composição das câmaras federais e estaduais. Texto para discussão GEMAA (IESP-UERJ). № 07, pp. 01-21.

CODATO, Adriano; LOBATO, Tiemi, and CASTRO, Andréa Oliveira (2017), 'VAMOS LUTAR, PARENTES!' As candidaturas indígenas nas eleições de 2014 no Brasil. Revista Brasileira de Ciências Sociais. Vol. 32, № 93, pp. 01-24.

COX, Gary W. (1997), Making votes count: strategic coordination in the world's electoral systems. Cambridge: Cambridge University Press. 360 pp..

ERIKSON, Robert; GOLDTHORPE, John H., and PORTOCARERO, Lucienne (1979), Intergenerational class mobility in three Western European societies: England, France and Sweden. The British Journal of Sociology. Vol. 30, № 04, pp. 415-441.

FIGUEIREDO Fo, Dalson Britto (2009), O elo corporativo? Grupos de interesse, financiamento de campanha e regulação eleitoral. Master's dissertation. Programa de Pós-Graduação em Ciência Política. Universidade Federal de Pernambuco.

FIGUEIREDO Fo, Dalson Britto; SANTOS, Manoel ; SILVA JR., José Alexandre, and ROCHA, Enivaldo (2011), Campaign spending and poverty levels in Brazil: an exploratory approach. Paper presented at 35을 Encontro da Anpocs- GT13.

HAO, Lingxin and NAIMAN, Daniel Q. (2007), Quantile regression. Thousand Oaks: Sage. 136 pp..

HASENBALG, Carlos and SILVA, Nelson do Valle (1999), Race, schooling and social mobility in Brazil. Ciência e Cultura. Vol. 51, pp. 457-463.

JACOBSON, Gary C. (1978), The effects of campaign spending in congressional elections. American Political Science Review. Vol. 72, № 02, pp. 469-491.

JOHNSON, Ollie A. (1998), Racial representation and Brazilian politics: black members of the National Congress, 1983-1999. Journal of Interamerican Studies and World Affairs. Vol. 40, № 04, pp. 97-118.

KOENKER, Roger W. (2005), Quantile regression (Econometric Society Monographs). Cambridge: Cambridge University Press. 366 pp..

KOENKER, Roger W. and BASSETT JR., Gilbert (1978), Regression quantiles. Econometrica. Vol. 46, № 01, pp. 33-50. 
KOENKER, Roger W. and HALLOCK, Kevin F. (2001), Quantile regression: an introduction. Journal of Economic Perspectives. Vol. 15, № 04, pp. 143-156.

LEMOS, Leany Barreiro; MARCELINO, Daniel, and PEDERIVA, João Henrique (2010), Porque dinheiro importa: a dinâmica das contribuições eleitorais para o Congresso Nacional em 2002 e 2006. Opinião pública. Vol. 16, № 02, pp. 366393.

LEVITT, Steven D. (1994), Using repeat challengers to estimate the effect of campaign spending on election outcomes in the US House. Journal of Political Economy. Vol. 102, № 04, pp. 777-798.

MANCUSO, Wagner Pralon (2015), Investimento eleitoral no Brasil: balanço da literatura (2001-2012) e agenda de pesquisa. Revista de Sociologia e Política. Vol. 23, № 54, pp. 155-183.

MANSBRIDGE, Jane (1999), Should blacks represent blacks and women represent women? A contingent 'yes'. The Journal of Politics. Vol. 61, № 03, pp. 628-657.

MIGUEL, Luis Felipe and QUEIROZ, Cristina Monteiro de (2006), Diferenças regionais e o êxito relativo de mulheres em eleições municipais no Brasil. Revista Estudos Feministas. Vol. 14, № 02, pp. 363-385.

MIGUEL, Luis Felipe; MARQUES, Danusa, and MACHADO, Carlos (2015), Capital familiar e carreira política no Brasil: gênero, partido e região nas trajetórias para a Câmara dos Deputados. Dados. Vol. 58, № 03, pp. 721-747.

MIGUEL, Sonia Malheiros (2000), A política de cotas por sexo: um estudo das primeiras experiências no legislativo brasileiro. Brasília: Centro Feminista de Estudos e Assessoria. 216 pp.

MILL, John Stuart (1964), Considerações sobre o governo representativo. São Paulo: Ibrasa. 236 pp..

MOSTELLER, Frederick and TUKEY, John Wilder (1977), Data analysis and regression: a second course in statistics. Nova York: Addison-Wesley Publishing Company. 588 pp..

NORRIS, Pippa and INGLEHART, Ronald (2001), Cultural obstacles to equal representation. Journal of Democracy. Vol. 12, № 03, pp. 126-140.

PEIXOTO, Vitor de Moraes (2010), Eleições e financiamento de campanhas no Brasil. Doctoral Thesis. Instituto Universitário de Pesquisa do Rio de Janeiro.

PEREIRA, Wescrey Portes (2018), Raça e eleições: apontamentos sobre os obstáculos à política de vereadores negros no Rio de Janeiro. Master's Dissertation. Instituto de Estudos Sociais e Políticos. Universidade Estadual do Rio de Janeiro. 


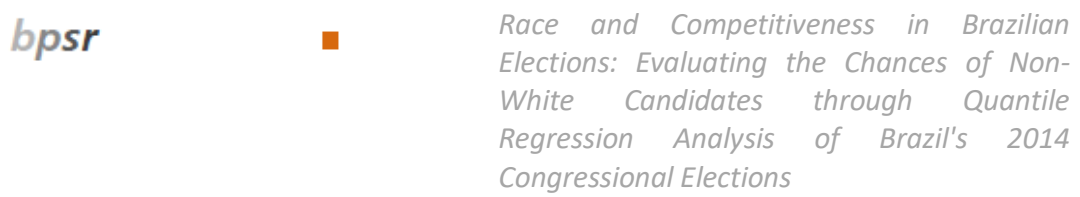

PERISSINOTTO, Renato Monseff and MIRÍADE, Angel (2009), Caminhos para o parlamento: candidatos e eleitos nas eleições para deputado federal em 2006. Dados. Vol. 52, № 02, pp. 301-333.

PINTO, Céli Regina Jardim (1994), Participação (representação?) política da mulher no Brasil: limites e perspectivas. In: Mulher brasileira é assim. Edited by SAFFIOTI, Heleieth Iara Bongiovani and MUÑOZ-VARGAS, Monica. Rio de Janeiro: Rosa dos Tempos. pp. 195-230.

RIBEIR0, Carlos Antonio Costa (2011), Desigualdade de oportunidades e resultados educacionais no Brasil. Dados. Vol. 54, № 01, pp. 41-87.

SAMUELS, David J. (2003), Ambition, federalism, and legislative politics in Brazil. Cambridge: Cambridge University Press. 266 pp..

SAMUELS, David J. (2002), Pork barreling is not credit claiming or advertising: campaign finance and the sources of the personal vote in Brazil. Journal of Politics. Vol. 64, № 03, pp. 845-863.

SAMUELS, David J. (2001), Incumbents and challengers on a level playing field: assessing the impact of campaign finance in Brazil. Journal of Politics. Vol. 63, № 02, pp. 569-584.

SILVA, Daniel Marcelino da (2010), Sobre dinheiro e eleições: um estudo dos gastos de campanha para o Congresso Nacional em 2002 e 2006. Master's Dissertation. Instituto de Ciências Sociais. Universidade de Brasília.

SPECK, Bruno Wilhelm and CERVI, Emerson Urizzi (2016), Dinheiro, tempo e memória eleitoral: os mecanismos que levam ao voto nas eleições para prefeito em 2012. Dados. Vol. 59, № 01, pp. 53-90.

WILSON, James (1896), Works. Vol. 01. Chicago: Callaghan. 
Appendix

Table A1. Comparison of models - linear regressions with campaign spending as a dependent

\begin{tabular}{lccccc}
\hline & M01 & M02 & M03 & M04 & M05 \\
& $\mathrm{m} 1$ & $\mathrm{~m} 2$ & $\mathrm{~m} 3$ & $\mathrm{~m} 4$ & $\mathrm{~m} 5$ \\
\hline \multirow{2}{*}{ Color/Race } & $-0.571^{* * *}$ & $-0.497^{* * *}$ & $-0.296^{* * *}$ & $-0.222^{* *}$ & -0.105 \\
& $(0.076)$ & $(0.074)$ & $(0.073)$ & $(0.071)$ & $(0.067)$ \\
Sex & & $-1.460^{* * *}$ & $-1.378^{* * *}$ & $-1.158^{* * *}$ & $-0.970^{* * *}$ \\
Higher Education & & $(0.079)$ & $(0.077)$ & $(0.077)$ & $(0.073)$ \\
& & & $1.304^{* * *}$ & $0.774^{* * *}$ & $0.663^{* * *}$ \\
Political Class & & & $(0.073)$ & $(0.078)$ & $(0.074)$ \\
& & & & $1.363^{* * *}$ & $1.092^{* * *}$ \\
Incumbency & & & & $(0.078)$ & $(0.076)$ \\
& & & & & $3.798^{* * *}$ \\
Constant & & & & & $(0.080)$ \\
Observations & $-8.022^{* * *}$ & $-7.645^{* * *}$ & $-8.597^{* * *}$ & $-9.179^{* * *}$ & $-9.298^{* * *}$ \\
$\mathrm{R}^{2}$ & $(0.051)$ & $(0.054)$ & $(0.073)$ & $(0.075)$ & $(0.071)$ \\
\hline Source: Ela & 5021 & 5021 & 5021 & 5021 & 5021 \\
& 0.011 & 0.069 & 0.119 & 0.168 & 0.288 \\
\hline
\end{tabular}

Source: Elaborated by the authors using 2018 electoral data from the TSE.

Note: Standard error in parenthesis $/{ }^{*} \mathrm{p}<0.05,{ }^{* *} \mathrm{p}<0.01,{ }^{* * *} \mathrm{p}<0.001$.

Table A2. Comparison of linear and quantile regression - campaign spending as a dependent

\begin{tabular}{lcccccc}
\hline & M01 & M02 & M03 & M04 & M05 & M06 \\
& Linear & $50 \%$ & $60 \%$ & $70 \%$ & $80 \%$ & $90 \%$ \\
\hline Color/Race & -0.105 & -0.042 & -0.064 & -0.069 & $-0.292^{* *}$ & $-0.433^{* * *}$ \\
& $(0.067)$ & $(0.074)$ & $(0.074)$ & $(0.091)$ & $(0.102)$ & $(0.111)$ \\
Sex & $-0.970^{* * *}$ & $-0.898^{* * *}$ & $-0.986^{* * *}$ & $-1.061^{* * *}$ & $-1.117^{* * *}$ & $-1.049^{* * *}$ \\
& $(0.073)$ & $(0.083)$ & $(0.088)$ & $(0.104)$ & $(0.114)$ & $(0.139)$ \\
Higher Education & $0.663^{* * *}$ & $0.679^{* * *}$ & $0.688^{* * *}$ & $0.823^{* * *}$ & $0.810^{* * *}$ & $0.985^{* * *}$ \\
& $(0.074)$ & $(0.081)$ & $(0.086)$ & $(0.102)$ & $(0.115)$ & $(0.123)$ \\
Political Class & $1.092^{* * *}$ & $1.116^{* * *}$ & $1.290^{* * *}$ & $1.447^{* * *}$ & $1.474^{* * *}$ & $1.549^{* * *}$ \\
& $(0.076)$ & $(0.081)$ & $(0.086)$ & $(0.104)$ & $(0.117)$ & $(0.147)$ \\
Incumbency & $3.798^{* * *}$ & $4.068^{* * *}$ & $3.537^{* * *}$ & $3.046^{* * *}$ & $2.416^{* * *}$ & $1.798^{* * *}$ \\
& $(0.080)$ & $(0.072)$ & $(0.066)$ & $(0.092)$ & $(0.110)$ & $(0.113)$ \\
Constant & $-9.298^{* * * *}$ & $-9.500^{* * *}$ & $-8.918^{* * *}$ & $-8.424^{* * *}$ & $-7.452^{* * *}$ & $-6.428^{* * *}$ \\
Observations & $(0.071)$ & $(0.079)$ & $(0.080)$ & $(0.101)$ & $(0.117)$ & $(0.148)$ \\
$\mathrm{R}^{2} /$ Pseudo-R $\dagger$ & 5021 & 5021 & 5021 & 5021 & 5021 & 5021 \\
F-test Linear Model & 0.288 & 0.179 & 0.193 & 0.202 & 0.203 & 0.174 \\
(Color/Race) & & 0.527 & 0.682 & 0.749 & 0.125 & 0.011 \\
F-test Anterior & & & & & & \\
Quantile (Color/Race) & & & 0.690 & 0.936 & 0.002 & 0.188 \\
\hline
\end{tabular}

Source: Elaborated by the authors using 2018 electoral data from the TSE.

Note: Standard error in parenthesis $/{ }^{*} \mathrm{p}<0.05,{ }^{* *} \mathrm{p}<0.01,{ }^{* * *} \mathrm{p}<0.001$. 
Figure A1. Distribution of proportion of votes in relation to electoral quotient

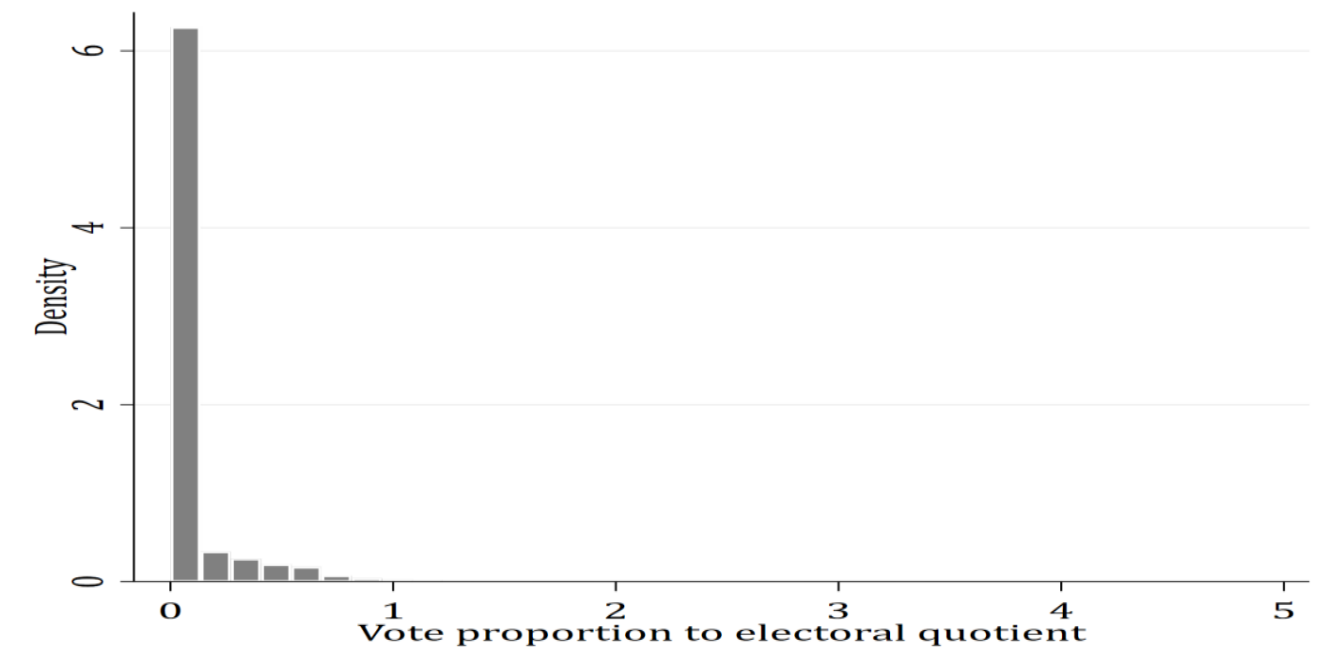

Source: Elaborated by the authors using 2018 electoral data from the TSE.

Note: Key: $y$ axis = density; $x$ axis = EQ vote proportion.

Figure A2. Distribution of proportion of votes in relation to electoral quotient with logarithmic transformation

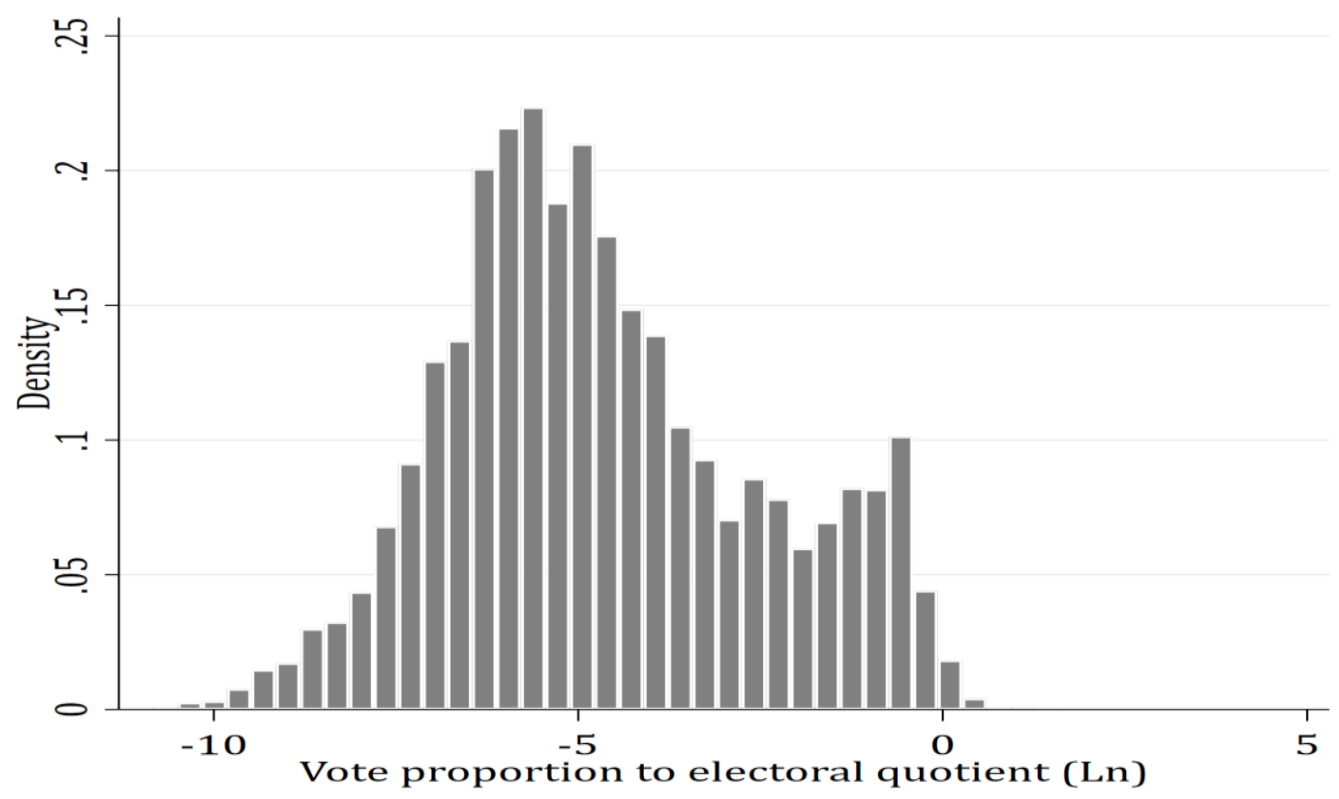

Source: Elaborated by the authors using 2018 electoral data from the TSE.

Note: Key: $y$ axis = density; $x$ axis = EQ vote proportion (Ln). 
Figure A3. Distribution of campaign spending

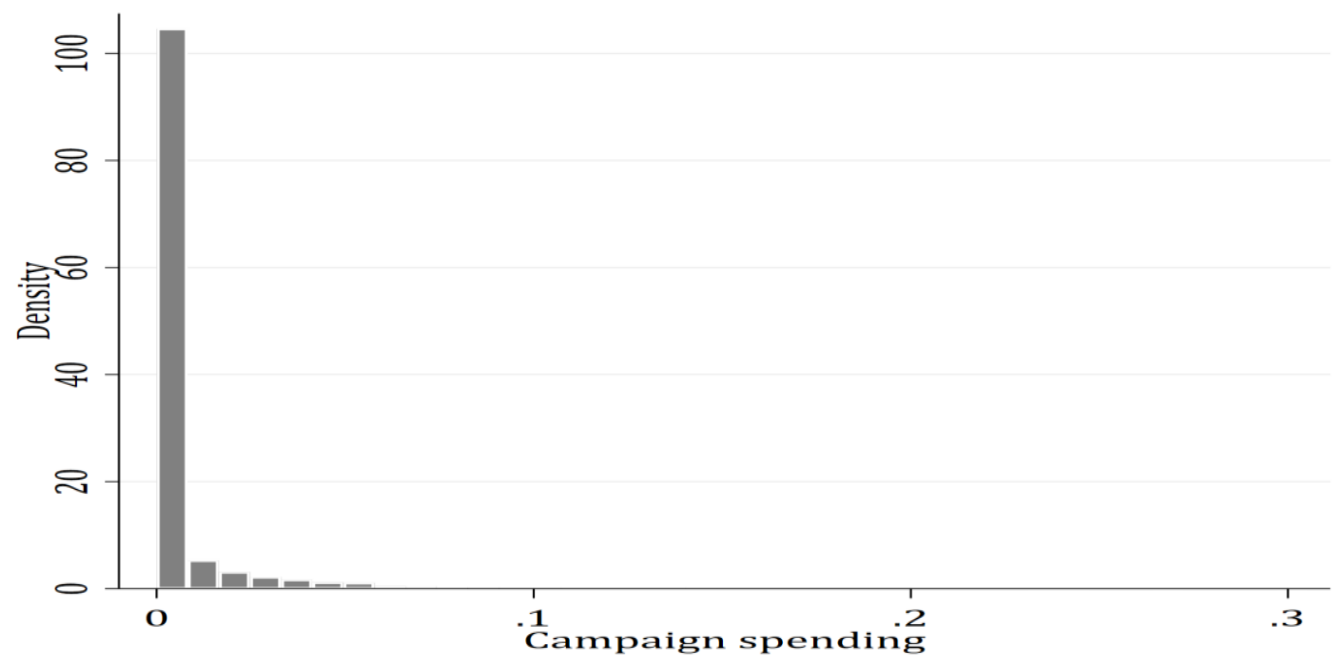

Source: Elaborated by the authors using 2018 electoral data from the TSE.

Note: Key: $y$ axis = density: $x$ axis = campaign spending.

Figure A4. Distribution of campaign spending with logarithmic transformation

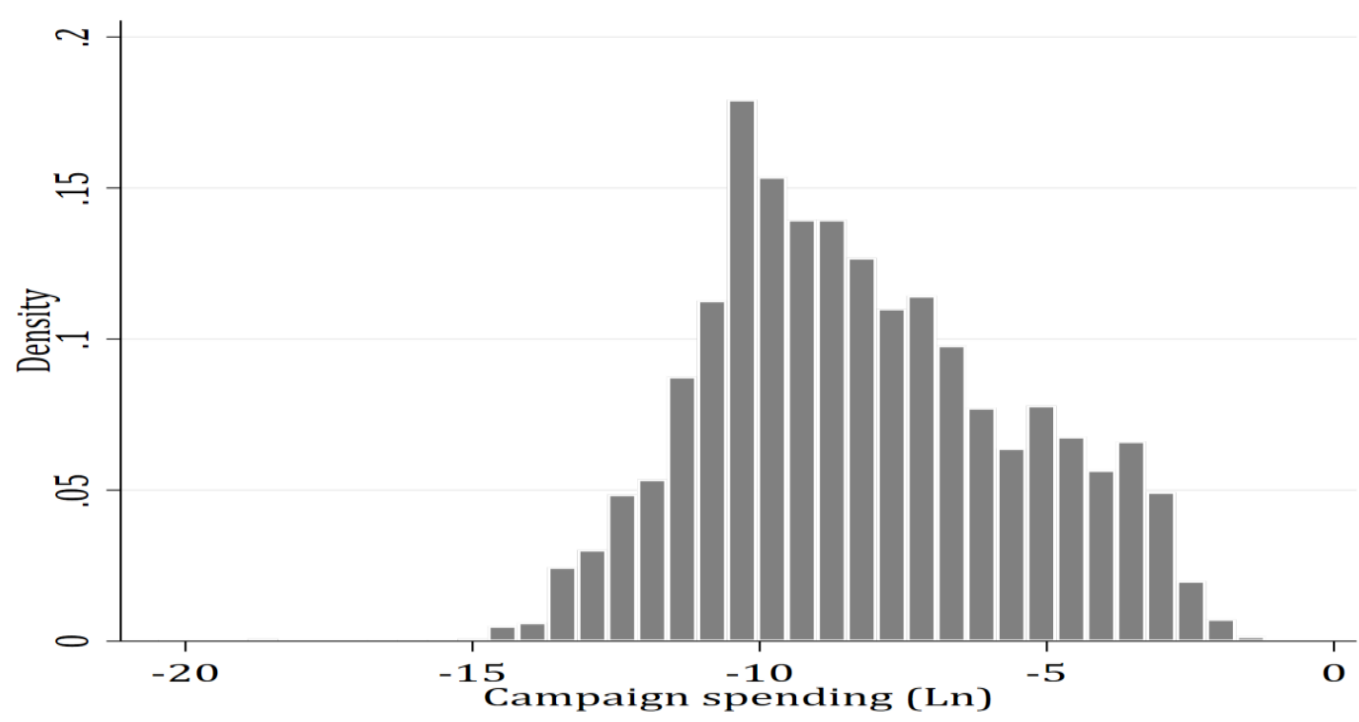

Source: Elaborated by the authors using 2018 electoral data from the TSE.

Note: Key: $y$ axis = density; $x$ axis = campaign spending. 
Figure A5. Boxplot campaign fundraising (Ln), per candidacy situation

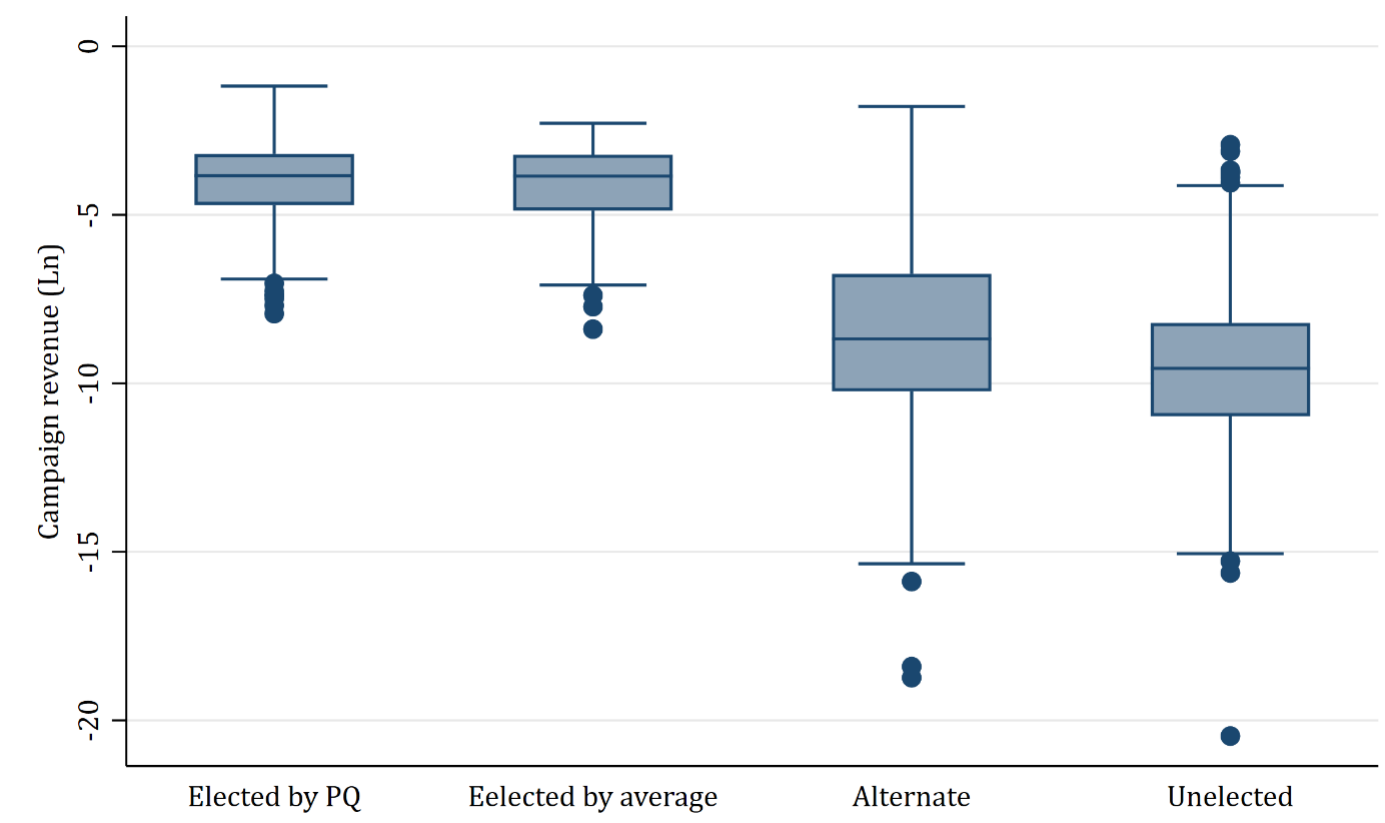

Source: Elaborated by the authors using 2018 electoral data from the TSE.

Note: Key: $y$ axis = campaign funds raised (Ln); $x$ axis = elected by PQ, elected by average, alternate, unelected.

Figure A6. Distribution of campaign funding

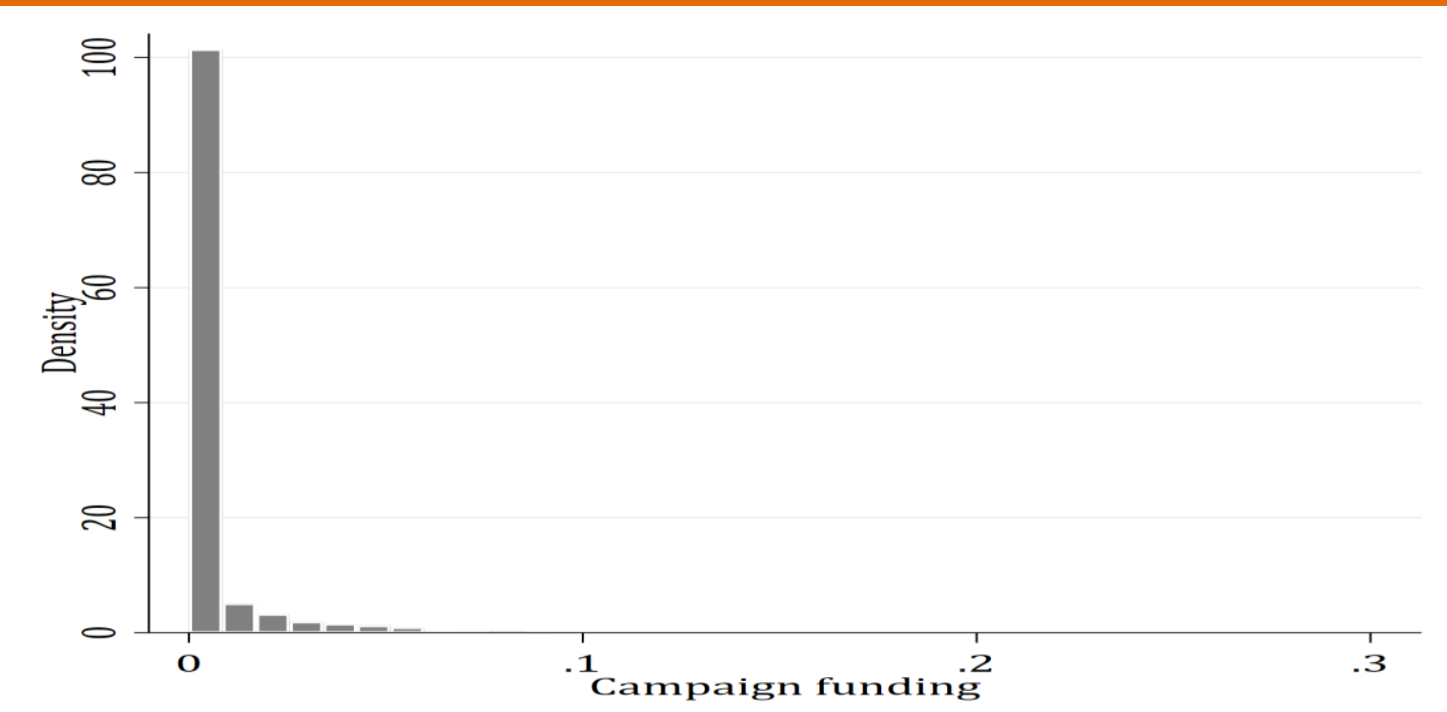

Source: Elaborated by the authors using 2018 electoral data from the TSE.

Note: Key: $y$ axis = density; $x$ axis = campaign funding. 
Figure A7. Distribution of campaign funding with logarithmic transformation

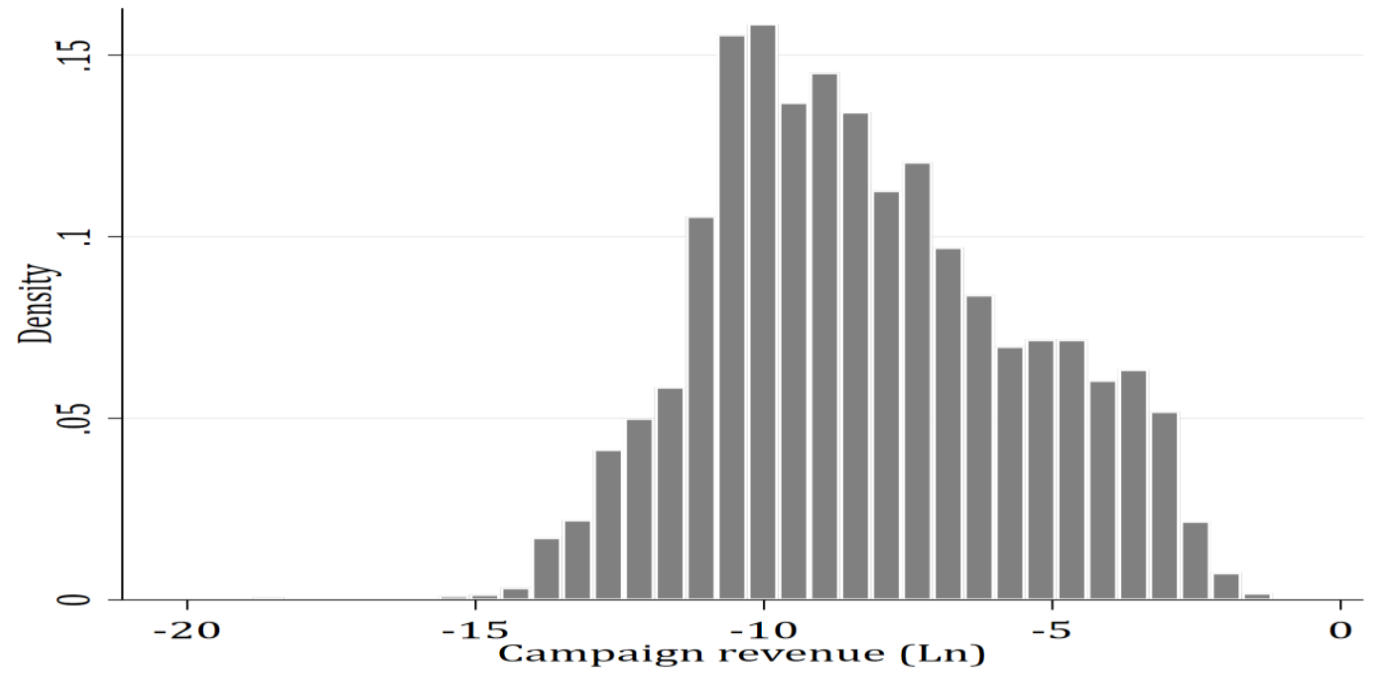

Source: Elaborated by the authors using 2018 electoral data from the TSE.

Note: Key: $y$ axis = density; $x$ axis = campaign funding (Ln).

Figure A8. Estimate of race/color in relation to campaign spending, starting from model 05 , linear and quantile $10-95$ with increments of 0.5 points

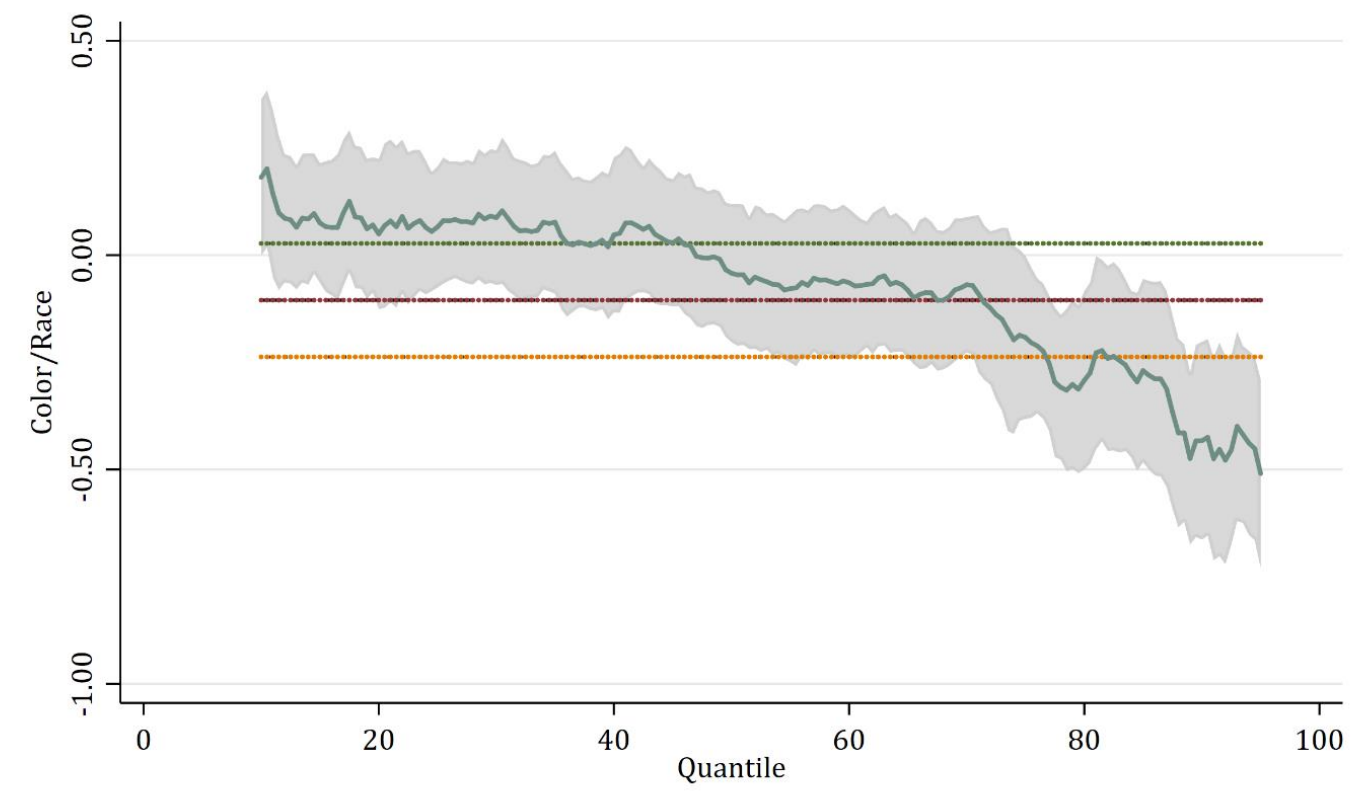

Source: Elaborated by the authors using 2018 electoral data from the TSE.

Note: Key: $y$ axis = color $/$ race; $x$ axis $=$ quantile. 